\title{
Mechanism and Compatibility of Pretreated Lignocellulosic Biomass and Polymeric Mixed Matrix Membranes: A Review
}

\author{
Abiodun Abdulhameed Amusa ${ }^{1}$, Abdul Latif Ahmad ${ }^{1, *(\mathbb{C})}$ and Jimoh Kayode Adewole ${ }^{2}$ \\ 1 School of Chemical Engineering, Engineering Campus, Universiti Sains Malaysia, \\ Nibong Tebal 14300, Pulau Pinang, Malaysia; aabiodun581@gmail.com \\ 2 Process Engineering Department, International Maritime College, Sohar 322, Oman; jimoh@imco.edu.om \\ * Correspondence: chlatif@usm.my; Tel.: +60-04-5996499
}

Received: 17 September 2020; Accepted: 5 November 2020; Published: 26 November 2020

\begin{abstract}
In this paper, a review of the compatibility of polymeric membranes with lignocellulosic biomass is presented. The structure and composition of lignocellulosic biomass which could enhance membrane fabrications are considered. However, strong cell walls and interchain hindrances have limited the commercial-scale applications of raw lignocellulosic biomasses. These shortcomings can be surpassed to improve lignocellulosic biomass applications by using the proposed pretreatment methods, including physical and chemical methods, before incorporation into a single-polymer or copolymer matrix. It is imperative to understand the characteristics of lignocellulosic biomass and polymeric membranes, as well as to investigate membrane materials and how the separation performance of polymeric membranes containing lignocellulosic biomass can be influenced. Hence, lignocellulosic biomass and polymer modification and interfacial morphology improvement become necessary in producing mixed matrix membranes (MMMs). In general, the present study has shown that future membrane generations could attain high performance, e.g., $\mathrm{CO}_{2}$ separation using MMMs containing pretreated lignocellulosic biomasses with reachable hydroxyl group radicals.
\end{abstract}

Keywords: mixed matrix membranes (MMMs); carbon dioxide; lignocellulosic biomass; pretreatment; mechanism

\section{Introduction}

The world population as estimated in 2020 was about 7.7 billion, with projected increases of about $30 \%$ by 2050 and around 2100, to 9.7 billion and 11.2 billion, respectively [1]. Enormous challenges accompany this. Of our primary concerns are polluting gases from different processes and industries that are emitted into the atmosphere. The well-known group of gases, greenhouse gases, includes carbon dioxide, methane, ozone, carbon fluorocarbons, and nitrous oxides as the main ones. If present in the atmosphere, these gases trap and radiate heat and absorb infrared radiation. The effects of these actions are evidenced in the climate problem and retention of heat during nighttime. The comparisons made among these gases have led to the recognition of the adverse effects from the amount of released carbon dioxide and have made it the main acid gas to be investigated to reduce greenhouse gases' effects [2-4].

According to the report from the Global Monitoring Laboratory of Earth System Research Laboratories at the National Oceanic and Atmospheric Administration, $\mathrm{CO}_{2}$ emission on a daily average basis for some locations is represented in Figure 1, which shows the average global levels. About $450 \mathrm{ppm}$ concentration of $\mathrm{CO}_{2}$ is present in the atmosphere [5]. Consistent rise in the emission of $\mathrm{CO}_{2}$ from energy use, of about $10 \%$, based on the different scenarios of transition evolving around 
us, will continue until 2040, based on the claims of the Energy Outlook from BP [6,7]. The introduction of carbon compounds in billions of tons into the atmosphere from the beginning of the industrial revolution until now will require a robust approach to mitigate. At present, $\mathrm{CO}_{2}$ elimination in the atmosphere is not exceeding half of the emitted amount, while the destruction of ozone layers and global temperature rise are among the harmful effects of leftover $\mathrm{CO}_{2}$. Prompt actions are required to solve this $\mathrm{CO}_{2}$ menace because it is affecting industrial activities such as reduction of flue gas heating values, industrial catalyst deterioration and poisoning, and transfer pipeline corrosion [8]. Therefore, a comprehensive and collective approach will be required for $\mathrm{CO}_{2}$ separation from the flue and natural gases with high purity and efficiency. Also, international laws and regulations must be enforced as mitigation measures while researchers are busy working on carbon capture, storage, and utilization.

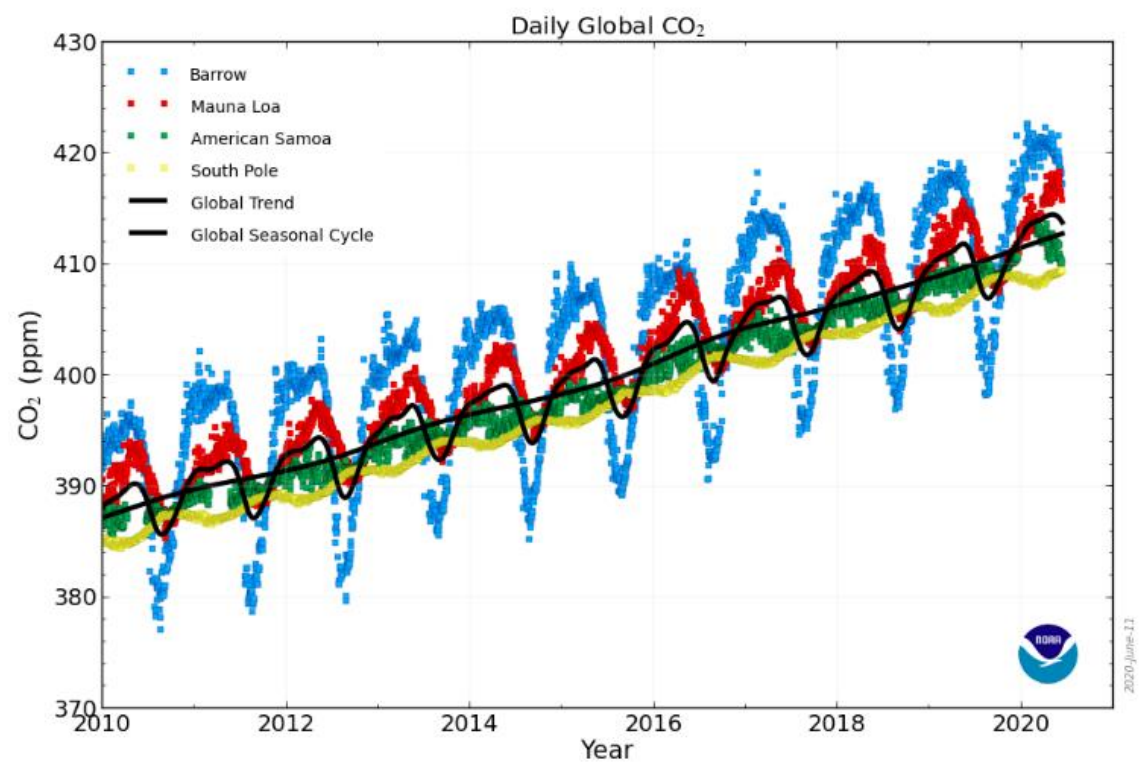

Figure 1. Recent trends in $\mathrm{CO}_{2}$ globally; reproduced from Reference [5].

An agreement was signed at the climate change convention held in Paris (2016) to increase the awareness of the negative impacts of $\mathrm{CO}_{2}$ on changes in the climate and to ensure that the temperature rise is limited to below $1.5^{\circ} \mathrm{C}$. The decision was made based on the outcomes from the earlier conventions on climate change and the Kyoto conventions held in 1992 and 1997 [9-11]. Natural gas purification by the removal of acid gases especially has passed through different separation processes such as absorption, adsorption, membranes, and cryogenic distillation. A description of each method can be found elsewhere [12,13]. Yang et al. [14] carried out the economic comparison for the power plant flue gas $\mathrm{CO}_{2}$ capture. They posited that the most cost-effective method is chemical adsorption and suggested that improving the performance of membranes can be an alternative for future promising gas separation. Preference given to membrane technologies in gas separation is revealed in Table 1. 
Table 1. Comparisons of Natural gas (NG) separation processes.

\begin{tabular}{|c|c|c|c|}
\hline $\begin{array}{l}\text { Separation } \\
\text { Process }\end{array}$ & Merits & Demerits & Ref. \\
\hline Absorption & $\begin{array}{l}\text { 1. Acid gases }\left(\mathrm{CO}_{2} \text { and } \mathrm{H}_{2} \mathrm{~S}\right) \text { removed } \\
\text { simultaneously } \\
\text { 2. Processing capacity and product } \\
\text { purity is high } \\
\text { 3. Efficiency is } 50-100 \%\end{array}$ & $\begin{array}{l}\text { 1. Physical solvent usage requires high partial } \\
\text { pressure. As such, it is not cheap } \\
\text { 2. Chemical solvent usage requires low partial } \\
\text { pressure, which makes acid gas purification } \\
\text { take a longer time } \\
\text { 3. Operating units' efficiency is low, especially } \\
\text { using the amine absorption process }\end{array}$ & [15-18] \\
\hline Adsorption & $\begin{array}{l}\text { 1. Can produce an output of high purity } \\
\text { 2. Remote field relocation of adsorbent, } \\
\text { at the time of equipment sizing } \\
\text { challenge, is easy } \\
\text { 3. Simple process }\end{array}$ & $\begin{array}{l}\text { 1. Lower product recovery despite the high } \\
\text { amount of used adsorbent } \\
\text { 2. Single pure product is most favored } \\
\text { 3. Poor performance at low pressure } \\
\text { 4. Adsorbent regeneration is expensive }\end{array}$ & [19-22] \\
\hline Membrane & $\begin{array}{l}\text { 1. Simplicity, versatility, low capital } \\
\text { investment, and easy operation } \\
\text { 2. High-pressure stability } \\
\text { 3. Product recovery is high } \\
\text { 4. Optimized weight and space } \\
\text { 5. Environmentally friendly }\end{array}$ & $\begin{array}{l}\text { 1. Permeate can be recompressed } \\
\text { 2. Permselectivity trade-off } \\
\text { 3. Purity is moderate as its capacity is low } \\
\text { 4. Available membranes are thermally unstable }\end{array}$ & [23-26] \\
\hline Cryogenic & $\begin{array}{l}\text { 1. Compared to other techniques, } \\
\text { recovery is relatively higher } \\
\text { 2. Product purity is also relatively high } \\
\text { 3. Operation is possible at high volume } \\
\text { and high pressure }\end{array}$ & $\begin{array}{l}\text { 1. Regeneration requires energy of high } \\
\text { intensity } \\
\text { 2. Scale-down is not economical } \\
\text { 3. Being a closed system that is highly } \\
\text { integrated, different feed streams operation is } \\
\text { challenging }\end{array}$ & {$[27-30]$} \\
\hline
\end{tabular}

\section{Membrane Materials and Gas Separation Mechanism}

The membranes for gas separation are two phases that are adjacent to each other acting as an interphase or selective barrier regulating the transport of gas mixtures. Membrane separation is an environmentally friendly process projected to be necessary as a solution to environmental problems, because the separation technique has an excellent downsizing footprint and easy operation. The gas separation process using membranes depends on the choice of materials to be used for membrane fabrications. The types of selected materials will affect the permeability, the structure/thickness of the membrane, and the choice of the design module. The module design configuration can be flat or hollow [31]. A significant gas separation using membrane technology favors the separation of gas molecules with different molecular sizes. Investigations have been intense to separate some perfluoro compounds (e.g., $\mathrm{SF}_{6}$ ) and the following combinations: $\mathrm{CO}_{2} / \mathrm{CH}_{4}, \mathrm{CO}_{2} / \mathrm{N}_{2}, \mathrm{O}_{2} / \mathrm{N}_{2}$, etc. In nanometers $(\mathrm{nm})$, the kinetic diameters of the common gases $\mathrm{H}_{2}, \mathrm{CO}_{2}, \mathrm{~N}_{2}$, and $\mathrm{CH}_{4}$ are 0.29 , $0.33,0.36$, and 0.38 , respectively. These values indicate the influence of the spherical size of the gas molecules, which is related to the mean free path of molecules in a gas. The mean free path of gas molecules connotes the average distance travelled by a particle without collision. Thus, a smaller kinetic diameter means a higher likelihood or possibility of collision between a gas molecule and another molecule $[32,33]$. The practical application of polymeric membranes has been established with other separation technologies such as dialysis and reverse osmosis. However, this field of membrane technology demands further development to achieve excellent separation performances [34].

Performance superiority of membranes is determined by the permeability level and selectivity for a targeted gaseous species during gas processing operations. Application is given significant consideration among other factors such as cost, feed solution composition, goals of separation, parameters of operation, and membrane fabrication technology compatibility before choosing between an inorganic or organic barrier. The polymeric membrane material development is inevitable, since the desired separation performance is yet to be achieved.

An important class of membrane materials that have received a lot of attention is the mixed matrix membrane (MMM) material. Composite (mixed matrix) membranes are obtained when a filler material 
(usually in solid phase) is integrated into a continuous matrix of the polymer [35]. The filler can be either an organic or inorganic material. The main aim is to capitalize on the micropores of inorganic fillers that may provide better interaction with any of the gas components, because not all inorganic fillers have good interaction with targeting gases [36]. Thus, by incorporating an organic or inorganic filler into a continuous polymer matrix, researchers can exploit the characteristic synergy that results from the nature of the microstructures of both materials.

The continuous polymer matrix and the organic fillers (which can be either synthetic or natural) are glassy and rubbery polymers of varying properties (Table 2) [37]. Glassy polymers are chemically and thermally stable. In turn, these properties reflect in their processability and permselectivity results. Polyethersulfone, polyetherimide, polycarbonate, poly(2,6-dimethyl-1,4-phenylene oxide), polymers of intrinsic microporosity (PIMs), polyimide, sulfonated poly(ether ketone), and cellulose acetate are some examples of glassy polymers [32]. The common rubbery polymers are polydimethylsiloxane and propylene oxide-amide copolymers. Therefore, careful selection of the polymer to be used demands thorough investigations.

Stereoisomerism, the polarity of functional group, rigidity, and interaction of chains must be considered to make the right choice of polymers for the manufacture of organic membranes. Two or more monomers can be polymerized to synthesize artificial polymers. The polymerization could be by using either of the three configurations: linear (e.g., polyethene), branching (e.g., polysulfone), or crosslinking (e.g., phenol-formaldehyde) chains/structures. Linear-chained polymers (also called thermoplastic polymers) are easy to mold at high temperatures and dissolve readily in organic solvents. However, the increasing temperature does not soften crosslinked polymers (also called thermosetting polymers) and gives slight dissolution in organic solvents. Ceramics and metals constitute the inorganic barriers. Ceramic membranes entail titanium or aluminium metals and carbides, nitrides, and oxides of nonmetals. These ceramic membranes possess inert properties that enhance their applications in environments that are overly acidic or basic. Cracking of these membranes due to their high-temperature sensitivity is a downside. As for metallic membrane formation, powdered stainless steel, palladium, or tungsten metals are deposited and sintered on a porous substrate. The best combinations of polymer, solvent, and nonsolvent are reported elsewhere for gas separations [23,38-40]. Figure 2 represents the dope formation and post-treatment flow chart to obtain defect-free membranes. In general, for organic membranes, it is very challenging to clean the fouling surface, as it is chemically and thermally unstable and the material is prone to degradation by microorganism. In contrast to organic membranes, inorganic membranes require differences in pressure drop to be accounted for by ensuring a specified thickness is fabricated, which usually results in a higher cost [41].

Table 2. Examples of organic and inorganic membrane classifications [40,42-44].

\begin{tabular}{cccc}
\hline \multicolumn{2}{c}{ Organic Membranes } & \multicolumn{2}{c}{ Inorganic Membranes } \\
\hline Synthetic & Natural & Ceramic & Metal \\
\hline Polytetrafluoroethylene & Rubber & Silica membrane & Palladium membrane \\
Polyvinylidene difluoride & Cellulose & Silicon membrane & Tungsten membrane \\
Polyamide-imide & Wool & Zeolite & Palladium alloy membrane \\
Polysulfone, etc. & Leather & Carbon & Nonpalladium membranes \\
\hline
\end{tabular}

The separation of gases across membranes is driven by the pressure differences between the feed (inlet raw material) and the product (outlet). If the system is a gas-fluid phase with the gradient of partial pressure as the driving force, the membrane structure should be dense/porous for efficient gas permeation evaluation $[45,46]$. Permeability and selectivity influence membrane performance. The size of the penetrants will affect the diffusion coefficient and permeability because the gas molecules will have sufficient space to move, as the polymer has free volume and its chains are flexible. The membrane selectivity is a function of the ratio of the membrane's permeability for relevant gases. Therefore, understanding the properties of the gas transport mechanism for a gas-fluid system is essential. 


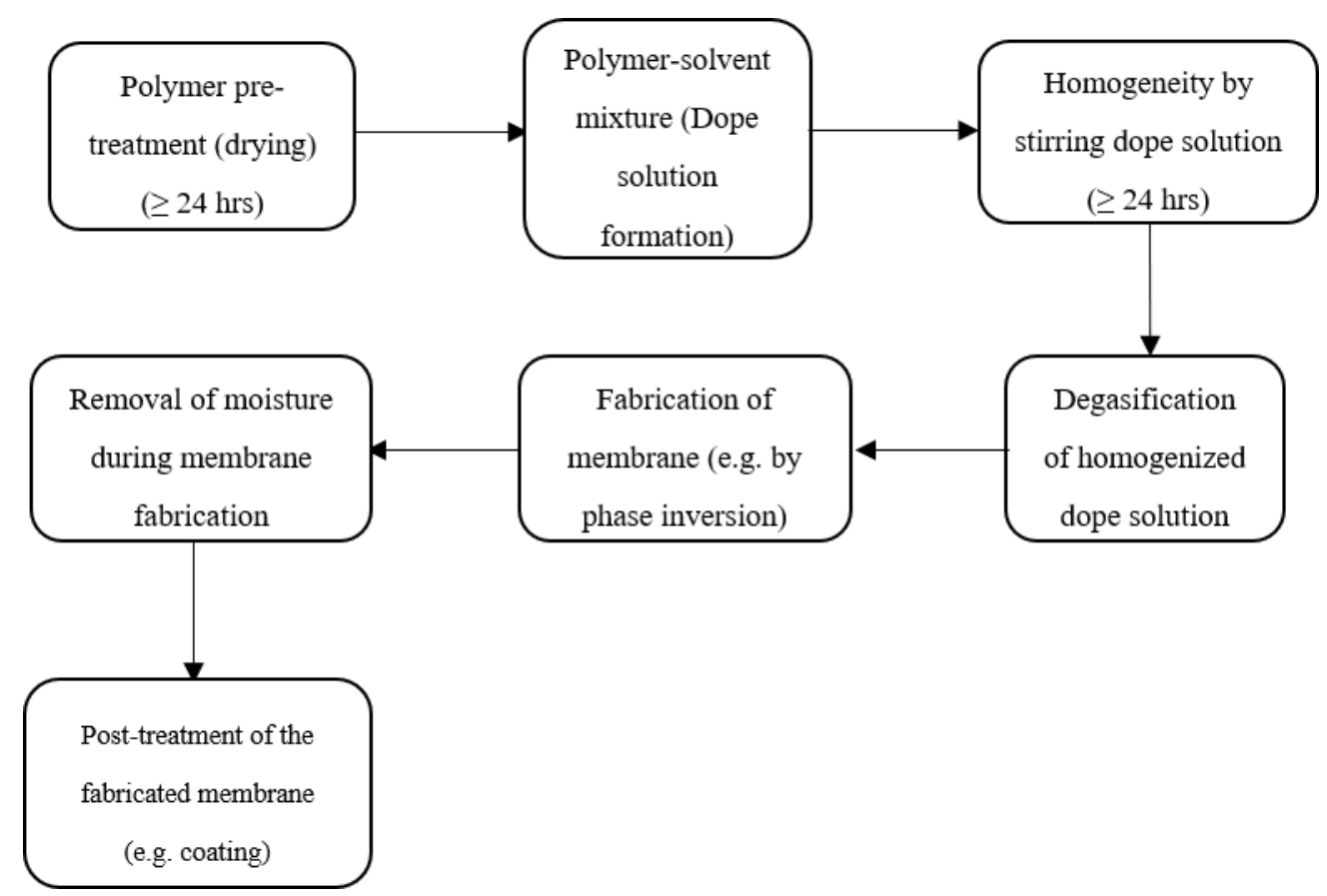

Figure 2. Defect-free membrane fabrication flow chart [41].

The mechanistic approach to transport (mass or energy) through a membrane depends on the module used. A module, also called the separation unit, is the specified smallest unit for packing membrane area. Installation of a membrane requires that the module is given priority, and using a single module is the simplest design. The permeate and retentate streams are separated feed streams that pass through as distance increases, which results in the decrease in both flow rate and concentration inside the module (Figure 3). Flat (e.g., spiral-wound and plate-and-frame modules) and tubular (e.g., hollow fiber, capillary, and tubular modules) configurations of membranes are used by researchers to design various modules [47]. The diameter of fiber size (in $\mathrm{mm}$ ) influences the choice of a module; if the diameter is less than 0.5 , between 0.5 and 10.0 , or more than 10.0 , the module choice will be hollow fiber, capillary, or tubular, respectively. A detailed description of these modules can be found elsewhere for spiral-wound [48-50], plate-and-frame [51-53], hollow fiber [24,54-59], capillary [60-64], and tubular [65-73] module configurations. The membrane module in the equipment receives the pumped gas, and the diffusivity and solubility differences enhance the targeted gas separation transport mechanism. In general, a module could be dead-end or crossflow (Figure 3). Microfiltration is frequently carried out using the dead-end module. In this, the membrane experiences feed forced on it, while the rejected component concentrations at the feed increase and permeate quality decreases with time. For instance, the downstream and upstream sides during ambient air gas separation using membrane produced nitrogen and oxygen, respectively [74]. The solubility coefficient $\left(S_{i}\right)$ is estimated by dividing the gas concentration in the polymer with the gas partial pressure in contact with it (Equation (1)), and its contributions to membrane transport mechanisms cannot be ignored.

$$
S_{i}=C_{i}\left(p_{i}\right)^{-1}
$$

The primary transport mechanisms are Knudsen diffusion and molecular sieving for pored membranes, and solution diffusion for dense membranes. Molecular sieving is designed to prevent specific larger molecules from passing through its small pores. Knudsen diffusion is applicable when pressure is low while the pore size of the material is relatively large and smaller molecules move faster through the pores than the larger ones. Both molecular sieving and Knudsen diffusion mechanisms are not practicable for gas separation because their molecular flow is convective and driven by pressure through a capillary and can be estimated using Darcy's law. The solution-diffusion mechanism is 
the most appropriate for gas separation (Figure 4). The diffusion coefficient $\left(D_{i}\right)$ is described using Fick's law (Equation (2)). Therefore, the product of Equations (1) and (2) can be used to evaluate the permeability (Equation (3)), where $C_{i}$ can be the gas concentration for the feed or the permeate sides as $C_{i, i}$ and $C_{i, f}$, respectively; while $p_{i}$ can be the partial pressure for the feed or the permeate sides as $p_{i, i}$ and $p_{i, f}$, respectively.

$$
D_{i}=J_{i} l\left(S_{i} \triangle P\right)^{-1}
$$

where $J_{i}$ is flux from Fick's law, 1 is the thickness of the membrane, and $\triangle P\left(p_{i, i}-p_{i, f}\right)$ is the difference in partial pressures from the feed and permeate sides.

$$
P_{i}=D_{i} S_{i}
$$

a. Crossflow module

Flow

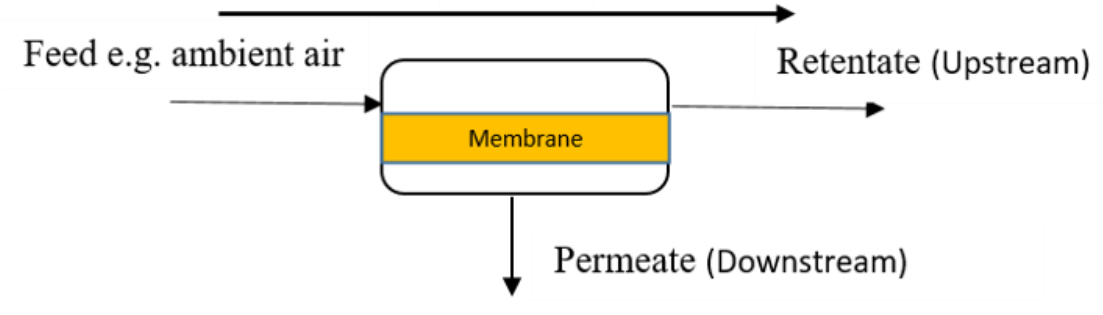

b. Dead-end module

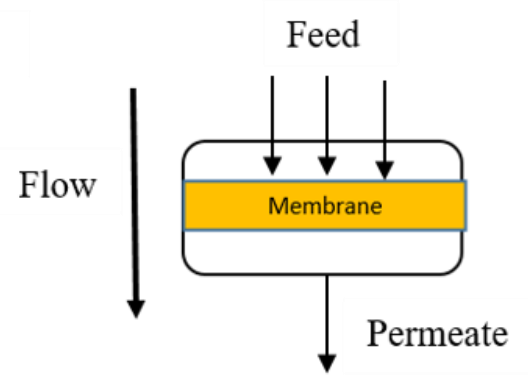

Figure 3. Basic schematics of two module operations: (a) crossflow module; (b) dead-end module.

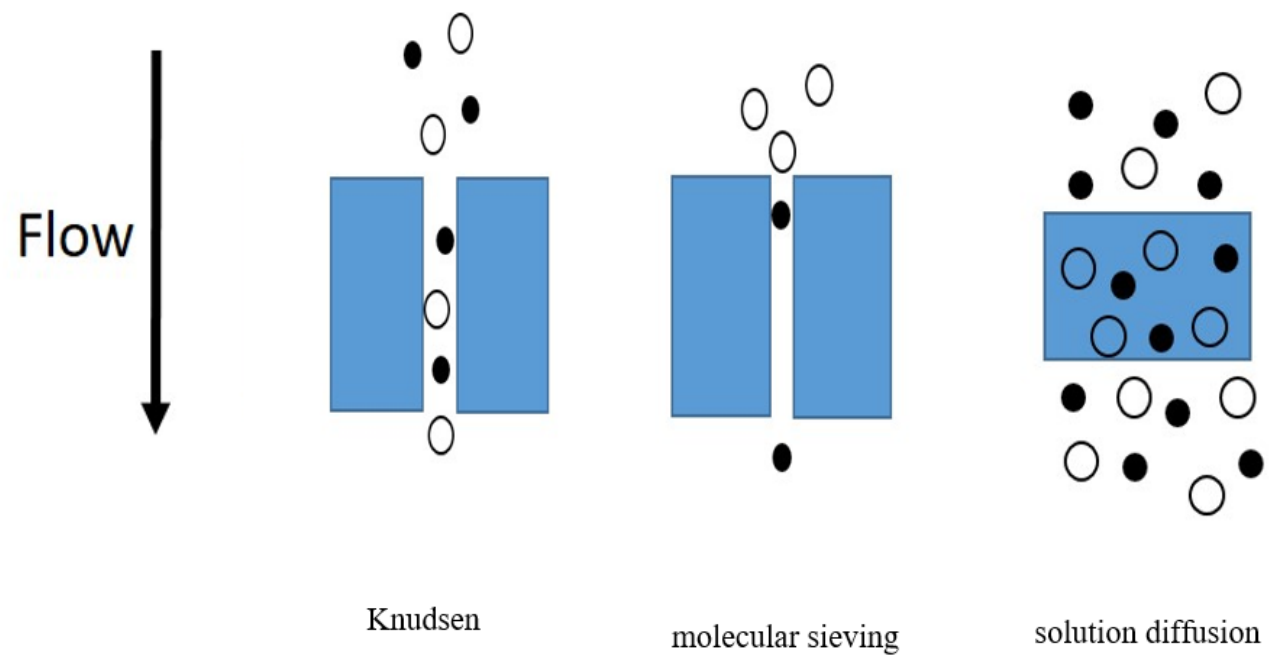

Figure 4. Schematic of membrane diffusion mechanisms; adapted from Reference [75].

Permeability is mostly expressed in barrer $\left(1\right.$ barrer $\left.=1 \times 10^{-10} \frac{\mathrm{cm}_{S T P}^{3} \mathrm{~cm}}{\mathrm{~cm}^{2} \mathrm{scmHg}}\right)$. In SI units, the expression for 1 barrer $=3.35 \times 10^{-16} \frac{\mathrm{mol} \mathrm{m}}{\mathrm{m}^{2} \mathrm{sPa}}$. However, the penetrant gas molecular weight $\left(M_{r}\right.$ in 
$\mathrm{mol} / \mathrm{g}$ ) must be accounted for while using the centimeter-gram-second (cgs) unit to estimate 1 barrer (Equation (4)).

$$
\text { I barrer }=M_{r} \times 3.35 \times 10^{-13} \frac{\mathrm{cm} \mathrm{g}}{\mathrm{cm}^{2} \mathrm{~s} \text { bar }}
$$

Gas permeance $\left(P_{i} / l\right)$, permeability divided by membrane thickness, is also commonly expressed in gas permeance units (GPU), where $1 \mathrm{GPU}=1 \times 10^{-6} \frac{\mathrm{cm}_{S T P}^{3}}{\mathrm{~cm}^{2} \mathrm{scmHg}}=1 \times 10^{-12} \frac{\mathrm{m}_{S T P}^{3}}{\mathrm{~m}^{2} \mathrm{sPa}}$ and $M_{r}(\mathrm{in} \mathrm{mol} / \mathrm{g}$ ) must be incorporated for the penetrant gas molecular weight for the SI unit conversion (Equation (5)).

$$
1 \mathrm{GPU}=M_{r} \times 3.35 \times 10^{-10} \frac{\mathrm{mol}}{\mathrm{m}^{2} \mathrm{~s} \mathrm{~Pa}}
$$

The membrane selectivity (second vital parameter) $\left(\alpha_{x / y}\right)$ is the membrane's separating ability, and it depends on the diffusion rate of the specified gas molecules. In this situation, it implies the ratio of the permeability of penetrants $x$ and $y$ (Equation (6)). $D_{x}\left(D_{y}\right)^{-1}$ and $S_{x}\left(S_{y}\right)^{-1}$ represent the diffusivity and solubility selectivities, respectively. The ratio of the size of the molecules influences the diffusivity selectivity (dominant) in glassy polymers. As for rubbery polymers, solubility selectivity gives the major contribution. However, for both glassy and rubbery polymers, when the fractional free volume is similar, they exhibit the same diffusivity and selectivity. Table 3 presents the permeability and selectivity trade-off for some polymers. In ideal situations, the upper bound lines are used for determining the best materials for membranes based on their separation performances [76-78].

$$
\alpha_{x / y}=P_{x} P_{y}^{-1}=D_{x} S_{x}\left(D_{y} S_{y}\right)^{-1}=D_{x}\left(D_{y}\right)^{-1} S_{x}\left(S_{y}\right)^{-1}
$$

For a low-recovery system, assuming temperature and permeability coefficients are constant, the gas separation conditions will be similar to the counter-flow. The feed side experiences plug flow while the permeate side is completely mixing, and it implies that mixing is thorough at the feed and permeate sides. The area of the membrane can be estimated by using Equation (7).

$$
A=\frac{q_{p, i}}{J_{i}}=\frac{q_{p} x_{p, i}}{J_{i}}
$$

while $J_{i}$ can be obtained from Equation (2), $q_{p}$, and $q_{p, i}$ are the permeate total mass flow rate and the mass flow rate of component $i$ in the permeate, respectively. 
Table 3. $\mathrm{CO}_{2} / \mathrm{CH}_{4}$ diffusion selectivities for some polymers.

\begin{tabular}{|c|c|c|c|c|c|}
\hline Polymers & $\underset{\text { (Barrer) }}{\text { Permeability }} P_{\mathrm{CO}_{2}}$ & $\begin{array}{l}\text { Diffusion Coefficient } D_{\mathrm{CO}_{2}} \\
\qquad\left(10^{-8} \mathrm{~cm}^{2} \mathrm{~s}^{-1}\right)\end{array}$ & Total Selectivity $\alpha_{\mathrm{CO}_{2} / \mathrm{CH}_{4}}$ & Diffusion Selectivity $D_{\mathrm{CO}_{2}} / D_{\mathrm{CH}_{2}}$ & Ref. \\
\hline Kapton polyimide & 2.7 & 0.56 & 46.0 & 11.9 & [79] \\
\hline Polysulfone & 5.6 & 2.00 & 22.0 & 5.9 & {$[79,80]$} \\
\hline Polycarbonate & 6.8 & 3.20 & 19.0 & 4.7 & [79] \\
\hline Polystyrene & 12.4 & 8.50 & 15.8 & 5.5 & [79] \\
\hline Poly(ethylene terephthalate) & 17.2 & 4.46 & 27.3 & 7.8 & [79] \\
\hline Polyisoprene & 153.0 & 125.00 & 5.1 & 1.4 & [79] \\
\hline Silicone rubber & 3800.0 & 2200.00 & 3.2 & 1.1 & [79] \\
\hline $\begin{array}{l}\text { Sulfonated poly(aryl ether ketone) } \\
\text { (SPEEK) }\end{array}$ & 15.0 & 4.89 & 26.5 & 2.8 & [81] \\
\hline Thermally rearranged polymers & 186.6 & 15.40 & 27.8 & 4.0 & [82] \\
\hline $\begin{array}{l}\text { Polymers of intrinsic microporosity } \\
\text { (PIMs) }\end{array}$ & 3672.0 & 172.00 & 10.6 & 3.9 & [82] \\
\hline Cellulose acetate & 218.0 & - & 13.8 & - & [83] \\
\hline Perfluoro polymers (Teflon AF 2400) & 2200.0 & - & 5.6 & - & [84] \\
\hline Poly(ether-block-amide) (Pebax ${ }^{\circledR}$ ) & 187.5 & - & 7.3 & - & [85] \\
\hline
\end{tabular}


It is worth mentioning that a membrane unit's capital cost can be reduced by reducing membrane thickness or modifying the chemistry of the membrane, which will result in membrane system size reduction and higher permeance. More so, the membrane system operating cost will be reduced since it is related to the required energy and the energy consumption depends on membrane selectivity. The majority of polymers used for membrane fabrications contain both crystalline and amorphous fractions. However, higher crystallinity results in higher resistance to diffusion. Reducing the amount of crystallinity in the membrane will affect the flux, diffusion rate, and transport mechanism of the membrane (Equation (8)).

$$
D_{i}=D_{i, 0} \quad B^{-1} \psi_{c}^{n}
$$

where $\psi_{c}(<0.1)$ is the crystalline amount present and $\mathrm{n}(<1)$ and B are an exponential factor and constant, respectively. So, gas performance improvement could be improved by using some techniques to pretreat the polymer membranes. These techniques are polymer backbone grafting [86,87], porogens usage with polymerization template [88,89], thermal and crosslinking [90,91], blending and copolymerization [92,93], phase inversion [94,95], polymer sulfonation [96-98], and the use of PIMs [99,100].

As a form of polymer pretreatment, Kang et al. [101] suggested surface binding increment for $\mathrm{CO}_{2}$ on polymers to improve gas separation by tuning metal ions. Also, Fontaine et al. [102] posited that $\mathrm{CO}_{2}$ with its Lewis acidic properties facilitates separation affinity, and Kundu et al. [103] stated that the uptake of $\mathrm{CO}_{2}$ would be massive in the presence of polymers with hetero elements that are rich in electrons, such as $-\mathrm{C}=\mathrm{O}$. Figure 5 shows the interaction of $\mathrm{CO}_{2}$ with polymers of pyridine and imidazole. The chemistry is due to the lone-pair electron nucleophilic attack. Therefore, this is a justification for the surface modifications to improve performances (permselectivity) by the incorporation of organic/inorganic materials (fillers) such as lignocellulosic biomasses into polymers to enhance their reaction mechanisms.
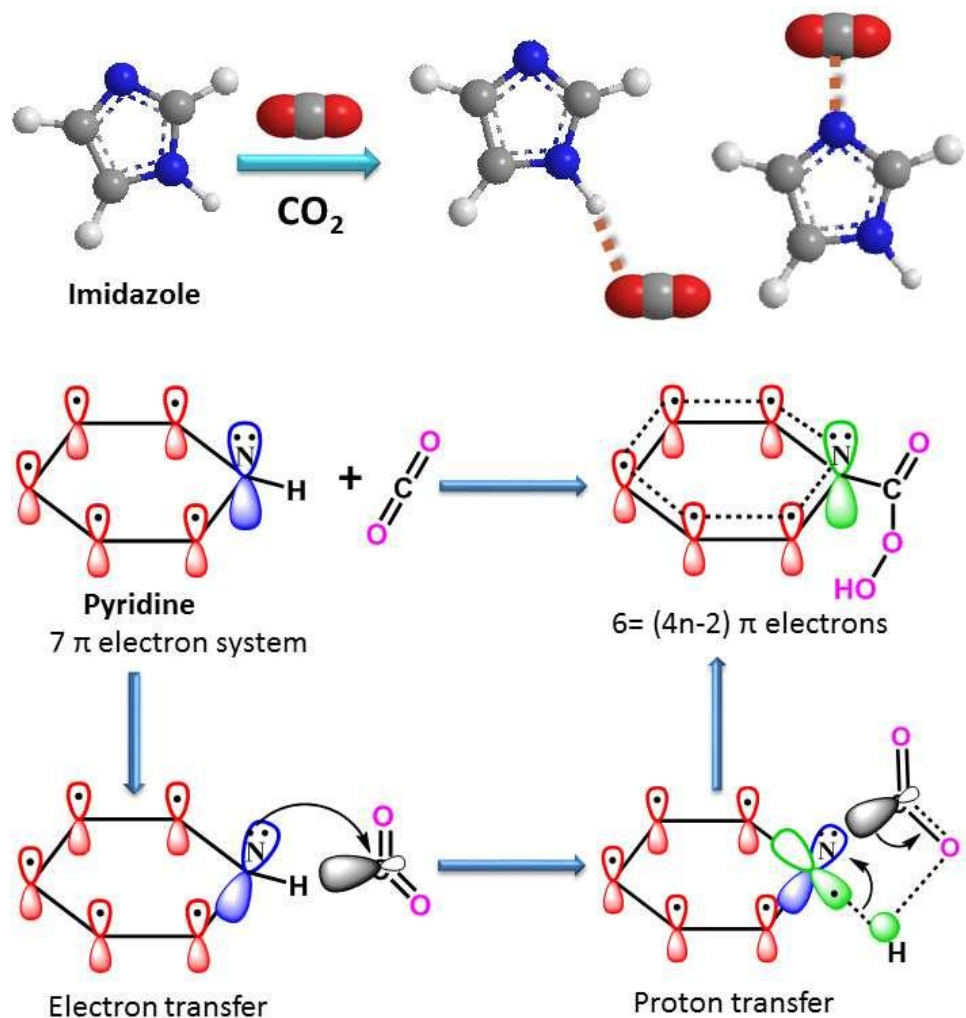

Figure 5. $\mathrm{CO}_{2}$ interaction mechanism with molecules of pyridine and imidazole polymers; reproduced from Reference [104]. 


\section{Lignocellulosic Biomasses Retrospect}

An annual estimation of total global agricultural waste materials produced in 2017 was about $37,522,440,479 \mathrm{~kg}$, with lignocellulosic biomass topping the list, which implies that large quantities of agro-wastes are available to be turned into resources [105]. The efficient use of lignocellulosic biomass requires significant study, understanding, and separation of its major complex components. Weak Van der Waals and hydrogen bonds hold these three components (lignin, hemicellulose, and cellulose) together within the plant cell walls [106].

The middle lamellae of opposite cell walls contain lignin, and it serves as the hydrophobic surface for water transport in plants to about $100 \mathrm{~m}$ height. Lignin also gives trees exceptional mechanical support of almost two kilometric tons and prevents invasion of pests and pathogens due to its chemical and physical properties [107-111]. However, high-value utilization of biomass has been faced with challenges attributed to rigidity, which leads to deconstruction resistance and recalcitrance affecting technological and economic conversion applications. Lignin poses a physical obstacle to direct access to cellulose, and biological and enzyme activities on biomass are diminished due to this recalcitrance [112-115]. Biofuels, paper, and pulp productions will increase if lignin presence in biomass can be effectively reduced. Nonproductive enzyme-to-lignin binding is another undesirable mechanism showing adverse effects of lignin on catalyst applications. This interaction between lignin and enzymes can be quantified by using the Langmuir adsorption isotherm analysis [116,117].

Different parts of trees contain varying lignin content with variable compositions: the shoots and wood have low and high lignin content, respectively $[118,119]$. There are three lignin subunits (Figure 6): First, guaiacyl units $(G)$ form softwood lignin and its polymer is derived from the monomers of coniferyl alcohol. Second, syringyl units (S) are formed from the polymerization of the monomer of sinapyl alcohol. Third, $p$-hydroxyphenol $(\mathrm{H})$ phenylpropanoid is a mixed $\mathrm{S}$ and $\mathrm{G}$ unit, which is common in hardwoods depending on the $\mathrm{S} / \mathrm{G}$ ratio [119]. Lignin also contains aromatic units (inset of Figure 6), namely coumaryl (a), coniferyl (b), and sinapyl (c) alcohols. The plant species have different units, and the bonding also differs. All plant species, especially softwoods, contain coniferyl alcohol. Crops and grasses mainly consist of coumaryl alcohol. About $40 \%$ of alcohol units in hardwoods are sinapyl units. Powerful C-C bonds and ether linkages keep the lignin structure together, which makes lignin insoluble in water. The reaction mechanism of lignin is challenging because its structure is highly complicated. Researchers are working on different routes to lignin breakdown. Some of these routes are ionic liquid usage, lignin esterification, supercritical carbon dioxide, and pyrolysis [120-123]. Hemicellulose and cellulose are less energy-intensive compared to lignin, as we will discuss next. Kumar et al. [124] established that lignin removal increases hemicellulose and cellulose accessibility, which will enhance their $\mathrm{OH}$ groups' availability for different applications. Wang Y. et al. [125] and Wang S. et al. [126] studied the effects of pretreatments on breaking lignin structural linkages to increase accessibility by increasing internal surface area. 


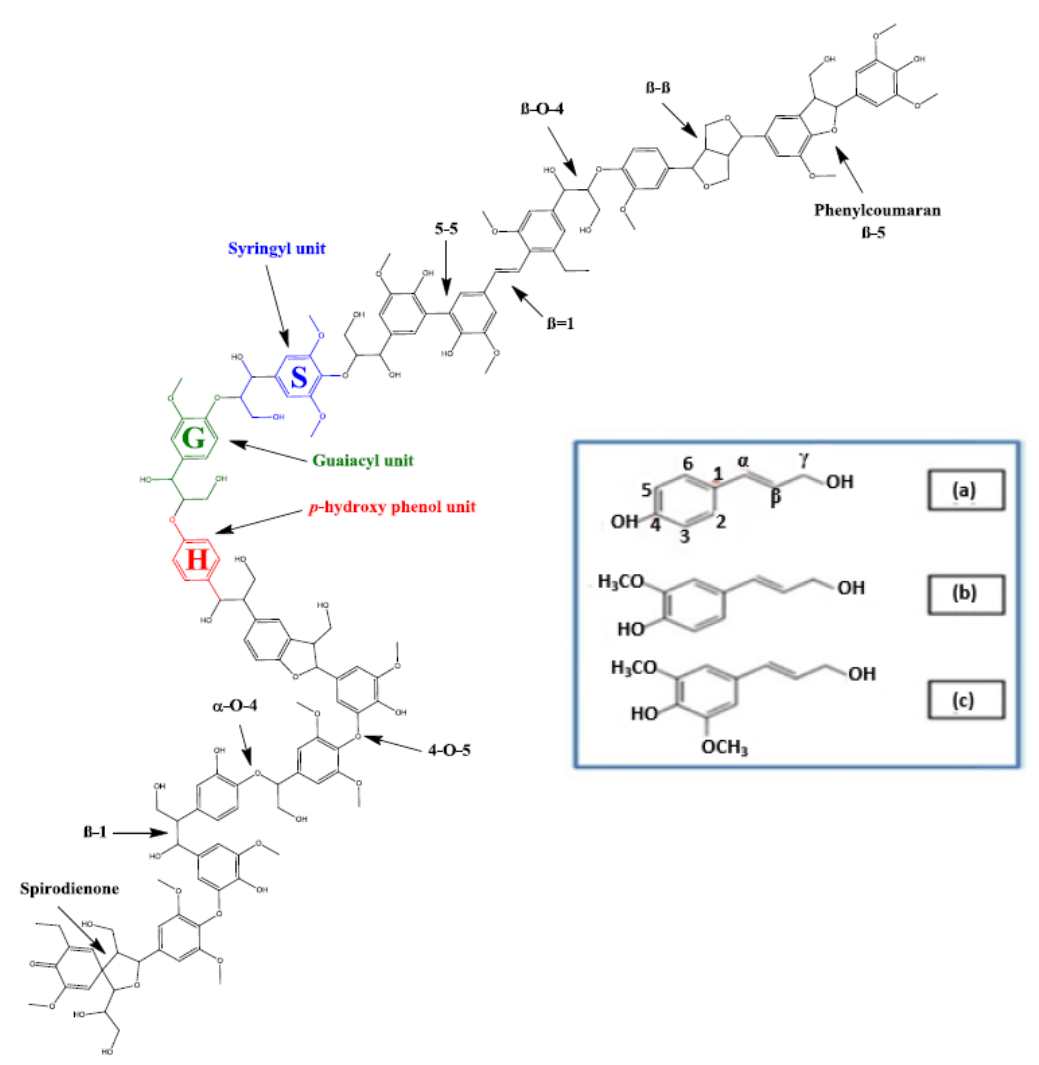

Figure 6. Subunits in the lignin structure; adapted from Reference [127].

Hemicelluloses are the second most abundant renewable polymers in lignocellulosic biomass after celluloses. Hemicelluloses are heterogeneous polysaccharides found in cell walls of plants. They have short chains, and are found in varying substituents and proportions [128-130]. Various applications can benefit from hemicellulose because they can be easily hydrolyzed, converted, and transformed [131]. Nonetheless, hemicelluloses also contribute to the resistances to the valorization of biomass. Cellulose extraction and quality of fiber and wood are affected due to hemicellulose presence. From the reaction mechanism, hardwood has different proportions of hemicelluloses with standard O-acetyl-4-O-methylglucuronoxylan components. At the xylopyranose backbone's second and third carbon, the hydroxyl group is about $70 \%[132,133]$. O-acetylgalactoglucomannan is the main component of hemicellulose in softwood. It consists of a $20 \%$ acetylated hydroxyl group, which was substituted partially by acetyl groups at the mannose units C-2 and C-3 $[134,135]$. Figure 7 shows hemicellulose sugar monomers that are of lower quantity in wood tissues and higher in some fruits' soft tissues and the pulp of sugar beet. 


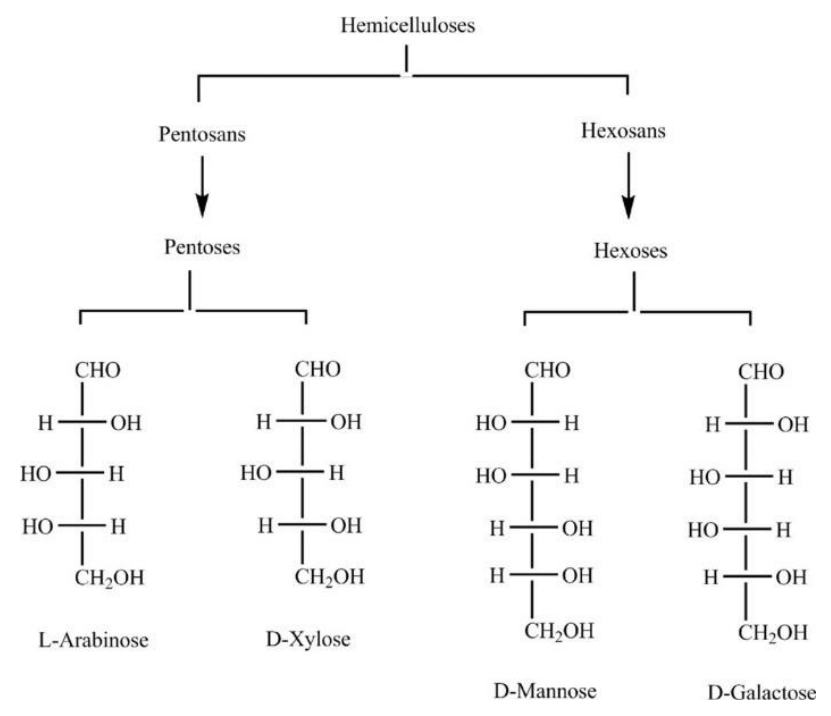

Figure 7. Hemicelluloses monomers; reproduced from Reference [136].

Cellulose is one of the main plant cell wall components, rendering the mechanical strength, and is the most abundant due to the continuous photosynthesis process $[137,138]$. Several sources of available routes to cellulose are known as agricultural waste and are yet to be fully maximized for other applications. However, the manufacturing of textiles, cardboard, paper, pharmaceuticals, biofuels, food, and nanocellulose materials have benefitted from the exciting chemistry of cellulose to some extent [139-142]. Cellulose's chemistry and mechanism depend on its high polydispersity. It is closely connected to other biopolymers such as lignin and hemicellulose. These other biopolymers have a challenging spatial arrangement. One glucose monomer in cellulose is called anhydroglucose units. Cellulose is a linear isotactic polymer with $180^{\circ}$ rotated neighboring monomer attachments. The attachment is made up of two glucose units (called cellobiose, repeating units). The monomer of glucose in cellulose is described as being in a chair conformation. The nonreducing end contains a glycosidic bond within its carbon atoms, while the reducing end converts its carbon to aldehyde. These two ends give balance (equilibrium) to cellulose [143-146]. The crystallinity and hydrogen bonding of cellulose is impacted. This impact is attributed to the numerous hydroxyl $(\mathrm{OH})$ groups present in its metastructure (Figure 8).

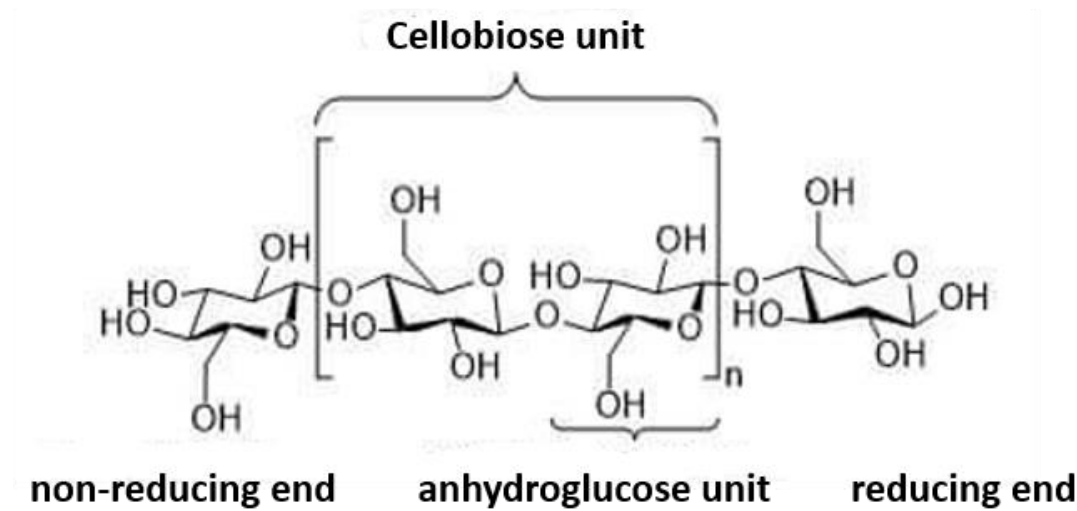

Figure 8. OH groups in the cellulose structure; reproduced from Reference [147].

Therefore, pretreatment is vital for the production of value-added products from lignocelluloses. It means that fractions of cellulose and hemicellulose should be made more accessible. The cellulose digestibility should also be increased by following sets of steps. The targeted actions aim at fractions 
of lignin to be bond-broken, solubilized and removed (Figure 9) [148-150]. Physical, chemical, physicochemical, biological methods and their combinations are the general pretreatment classification processes [151]. Enzyme, feedstock, and organism compatibility influence the pretreatment choice. The detailed lignocellulosic biomass pretreatments are beyond the scope of this review and can be found elsewhere [152-155]. However, an overview is given in Table 4.

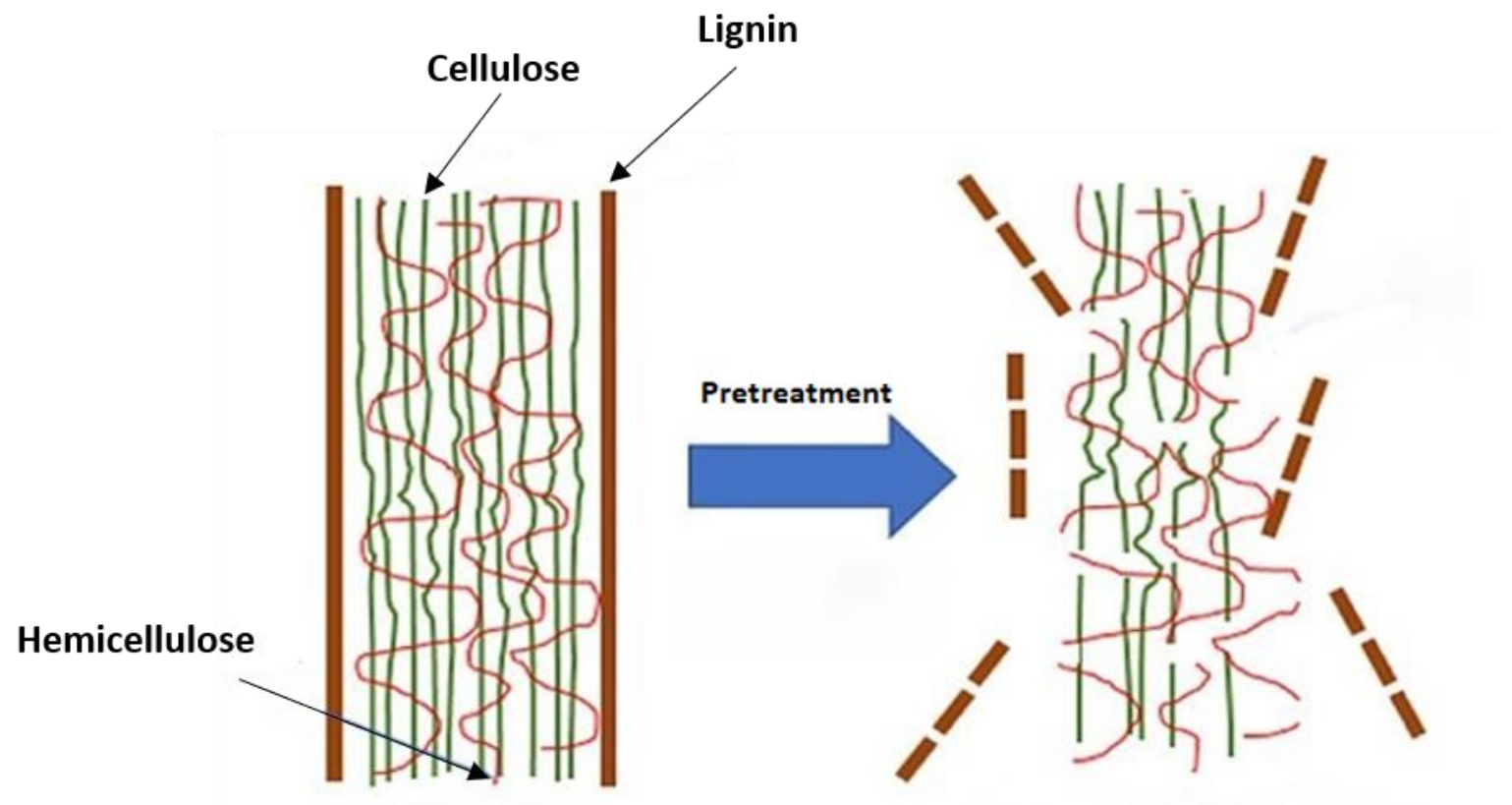

Figure 9. The role of pretreatment; reproduced from Reference [156].

Table 4. Comparison of methods of lignocellulosic biomass pretreatments.

\begin{tabular}{ccccc}
\hline Pretreatment Type & Examples & Uniqueness & Ref. \\
\hline Physical & $\begin{array}{c}\text { Mechanical, ultrasonic, } \\
\text { high-temperature/energy pyrolysis, } \\
\text { electron radiation, and microwave }\end{array}$ & $\begin{array}{c}\text { It requires high energy and cost to } \\
\text { reduce crystallinity and particle size }\end{array}$ & {$[$ [157-160] } \\
\hline Chemical & $\begin{array}{c}\text { Pretreatments using alkali, organosolv, } \\
\text { acids (dilute and concentrated), } \\
\text { oxidation, and ionic liquids }\end{array}$ & $\begin{array}{c}\text { The extraction of pure components is at } \\
\text { a high cost }\end{array}$ & {$[$ [161-163] } \\
\hline Physicochemical & $\begin{array}{c}\mathrm{CO}_{2} \text { explosion by Ammonia fiber } \\
\text { explosion (AFEX) method, steam } \\
\text { explosion, and electrical catalysis }\end{array}$ & $\begin{array}{c}\text { Occurrences at high temperature and } \\
\text { pressure: hemicellulose solubilization, } \\
\text { lignin transformation, and cellulose } \\
\text { surface area increases. }\end{array}$ & {$[164,165]$} \\
\hline Biological & Enzymolysis & $\begin{array}{c}\text { Despite low hydrolysis rate and energy } \\
\text { consumption, degradation of lignin and } \\
\text { hemicellulose is achievable }\end{array}$ & {$[166,167]$} \\
\hline
\end{tabular}

AFEX: Ammonia fiber explosion.

Finally, complex components of lignocellulosic biomasses can be solubilized by combining these pretreatment methods. The outputs from physical and chemical pretreatments were relatively good even though they were attributed to severe pollution and strict equipment requirements. Although they release less pollution compared to other methods and have lower energy consumption, biological processes are time-consuming and expensive. Li et al. [168] studied different techniques to alter the lignin contents in crops to improve cellulose and hemicellulose accessibility. The primary outcome of their study was that genetic engineering of lignin biosynthesis relied on monolignol pathway up- or down-regulation. Plant fitness, viability, and biofuel applications will be disfavored when total lignin 
is reduced. Finally, plant manipulation to ease enzyme or alkaline hydrolysis of lignin linkages will improve biomass applications.

\section{Perspective and Prospects for $\mathrm{CO}_{2}$ Separation}

Lignocellulosic biomass pretreatment becomes necessary. The necessity is due to an increase in the accessible surface area and the hydroxyl groups, lignin removal, and cellulose decrystallization. One of the ways to solve the trade-off of polymeric membranes is the incorporation of organic/inorganic materials to produce mixed matrix or composite membranes [169,170]. The lignocellulosic biomass-based MMM hybrid system begins with the targeted gas molecules being sorbed by the membrane. The adsorption occurs at high pressure due to the interaction with the filler (lignocellulosic biomass), diffuses through the membrane and then desorbs at the low pressure. The thermodynamic parameter (solubility coefficient) and the kinetic parameter (diffusivity coefficient) control this mechanism. As discussed in earlier sections, gas separations and other applications have benefitted from these concepts. This review examines the compatibility of polymers and lignocellulosic biomass. Cellulose extraction has been performed by solubilizing lignin, followed by incorporation into a polymer matrix after improving its intermolecular and intramolecular bonding [171]. These easily accessed $\mathrm{OH}$ groups will aid carbon dioxide capture because of the mechanism between $\mathrm{CO}_{2}$ and $\mathrm{OH}$ radicals. Table 5 presents the extraction techniques of cellulose.

Table 5. Cellulose sources and extraction techniques [172].

\begin{tabular}{|c|c|c|c|c|}
\hline Cellulose Sources & Preparation Techniques & Particle Size & Remarks & Reference \\
\hline Pineapple peel juice & Spray coating & NA & Enhanced spread factor & [173] \\
\hline $\begin{array}{l}\text { Trunks and fronds of oil } \\
\text { palm, okra }\end{array}$ & Alkaline, electrospinning & Less than $500 \mathrm{~nm}$ & $\begin{array}{l}\text { Binding and antioxidant } \\
\text { activities increased }\end{array}$ & [174] \\
\hline Canola straw & nanowelding & $53 \pm 16 \mathrm{~nm}$ & $\begin{array}{l}\text { High transparency and } \\
\text { biodegradability }\end{array}$ & [175] \\
\hline Rice husk & $\begin{array}{l}\text { Hydrothermal approach, } \\
\text { acid-alkali treatment, } \\
\text { mechanical disruption }\end{array}$ & $30-40 \mathrm{~nm}$ & Thermally stable & [176] \\
\hline Corn & TEMPO-mediated oxidation & NA & $\begin{array}{l}\text { High strength, elastic } \\
\text { modulus, and value of } \\
\text { water retention }\end{array}$ & [177] \\
\hline Achira & $\begin{array}{c}\text { Acid hydrolysis, high-pressure } \\
\text { homogenization }\end{array}$ & $13.8-37.2 \mathrm{~nm}$ & $\begin{array}{l}\text { Mechanically stable, } \\
\text { biodegradable, and } \\
\text { highly crystalline }\end{array}$ & [178] \\
\hline Paper waste residue & $\begin{array}{c}\text { Etherification of pulp, } \\
\text { mechanical disintegration }\end{array}$ & $10-100 \mathrm{~nm}$ & $\begin{array}{l}\text { Thermally stable with } \\
\text { high fibrillation potential }\end{array}$ & [179] \\
\hline Banana peel & $\begin{array}{l}\text { Chemical treatment, } \\
\text { high-intensity ultrasonication }\end{array}$ & NA & $\begin{array}{l}\text { Highly thermally stable } \\
\text { with high crystallinity }\end{array}$ & {$[180,181]$} \\
\hline $\begin{array}{l}\text { Poplar wood powder, } \\
\text { culms of Moso bamboo, } \\
\text { rice straw, corn straw }\end{array}$ & $\begin{array}{l}\text { Chemical pretreatment, } \\
\text { high-intensity ultrasonication, } \\
\text { high-pressure homogenization }\end{array}$ & $5-20 \mathrm{~nm}$ & $\begin{array}{l}\text { Highly crystalline and } \\
\text { thermally stable }\end{array}$ & {$[182,183]$} \\
\hline $\begin{array}{l}\text { Seagrass species balls } \\
\text { and leaves }\end{array}$ & $\begin{array}{l}\text { Chemical treatment, } \\
\text { fibrillation }\end{array}$ & $\begin{array}{l}\text { 5-21 nm and } \\
2-15 \mathrm{~nm}\end{array}$ & $\begin{array}{l}\text { Transparent and } \\
\text { biodegradable }\end{array}$ & [184] \\
\hline Tomato peels & $\begin{array}{c}\text { Acidified sodium chlorite, } \\
\text { chlorine-free alkaline peroxide }\end{array}$ & $260 \pm 79 \mathrm{~nm}$ & Highly crystalline & [185] \\
\hline
\end{tabular}

TEMPO: catalyst used in organic synthesis as an oxidant.

Mixed matrix membranes for various applications have been fabricated by incorporating cellulose extracted from natural agro-based sources into polymers, carbon, etc. (Table 6). A search of electronically available literature with keywords such as lignocellulose and membranes revealed that most biorefining research works are focused on biofuel, bioethanol, etc. The forerunner in the valorization of lignocellulosic biomass is the ChemPubSoc Europe organization. This organization constitutes 16 chemical societies. It shows the importance of lignocellulosic biomass as an alternative feedstock for 
energy, environmental, and crude oil substitute applications. The valorization will open the doors for interdisciplinary collaborations with colleagues working on catalysis and reaction engineering, among others. So, its usage as fillers in membrane fabrications cannot be overemphasized.

The polymer forms the continuous phase, while the cellulose forms the dispersed phase. Therefore, the polymer and filler must be carefully selected, since a defective morphology is obtained when the rigidification of the surrounding polymer matrix occurs due to the effect of the dispersed phase causing a void at the continuous and dispersed interface. Gas separation, water purification, tissue engineering, food packaging, etc. enjoy the remarkable properties of the mixed matrix membranes from cellulose due to their excellent mechanical strength. Elrasheedy et al. [186] reviewed water applications of membranes. Also, O'Harra et al. [187] fabricated composite membranes for gas separation. Supercapacitor electrodes are produced from carbon nanotube and cellulose combinations. Researchers are working on modifications of polymers and extracted cellulose for environmental, gas separation benefits, etc., including modifying cellulose to reduce its crystallinity and particle size to the nanoscale, increase its tensile strength and access to its hydroxyl group radicals, and use several functional groups. Polymers have been modified using different functional groups, such as amine [188], aniline [189,190], methacrylate [191-193], polyvinyl alcohol [194,195], and polyethylene oxide [196].

Table 6. Cellulose-based mixed matrix and other details.

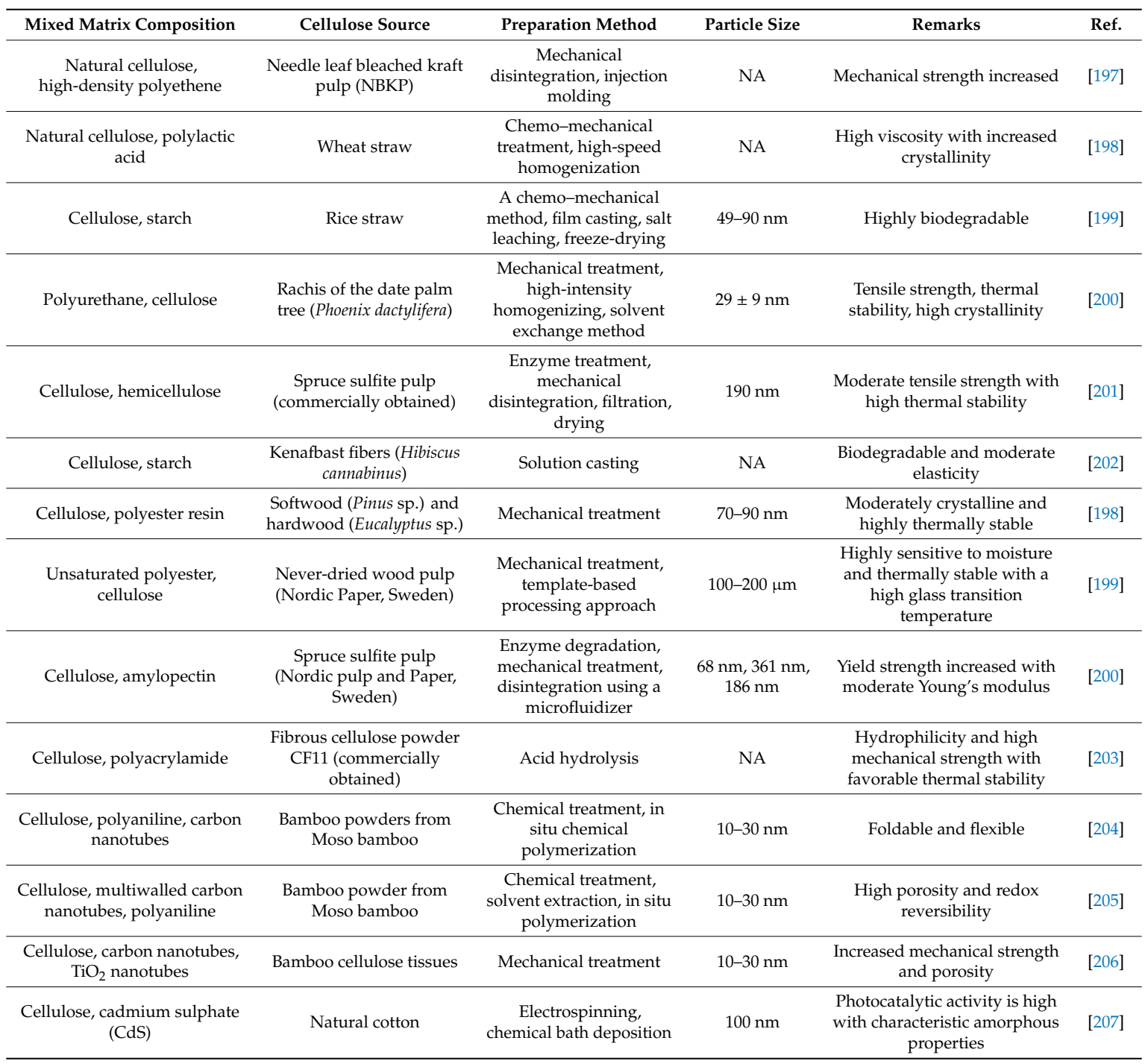


Table 6. Cont.

\begin{tabular}{|c|c|c|c|c|c|}
\hline Mixed Matrix Composition & Cellulose Source & Preparation Method & Particle Size & Remarks & Ref. \\
\hline $\begin{array}{l}\text { Titanium dioxide }\left(\mathrm{TiO}_{2}\right), \\
\text { cellulose, gold }(\mathrm{Au}) \text {, silver } \\
(\mathrm{Ag})\end{array}$ & $\begin{array}{l}\text { Eucalyptus pulp (USDA } \\
\text { Forest Service, Forest } \\
\text { Products Laboratory, } \\
\text { Madison, WI, USA) }\end{array}$ & $\begin{array}{l}\text { TEMPO-mediated } \\
\text { oxidation, mechanical } \\
\text { treatment }\end{array}$ & $4-20 \mathrm{~nm}$ & $\begin{array}{c}\text { Reusable, with improved } \\
\text { photocatalytic activities and } \\
\text { high tensile strength }\end{array}$ & [208] \\
\hline $\begin{array}{l}\text { Cellulose, quaternary } \\
\text { ammonium }\end{array}$ & Softwood kraft pulp & Mechanical treatment & $10-40 \mathrm{~nm}$ & Reusable and highly porous & [209] \\
\hline $\begin{array}{l}\text { Polyethylene- } b \text {-poly(ethylene } \\
\text { glycol), cellulose }\end{array}$ & $\begin{array}{c}\text { Cellulose nanofibers } \\
\text { (Commercially obtained) }\end{array}$ & $\begin{array}{l}\text { Spray drying, surface } \\
\text { adsorption, extrusion }\end{array}$ & NA & High modulus tension & [210] \\
\hline Cellulose, polyvinyl alcohol & $\begin{array}{l}\text { Microcrystalline cellulose } \\
\text { (commercially obtained) }\end{array}$ & Acid hydrolysis & $10-65 \mathrm{~nm}$ & $\begin{array}{c}\text { Thermally stable and } \\
\text { water-resistant }\end{array}$ & [211] \\
\hline Cellulose, polylactic acid & $\begin{array}{l}\text { Cellulose nanofibers } \\
\text { (Commercially obtained) }\end{array}$ & Solvent casting & $28 \pm 10 \mathrm{~nm}$ & $\begin{array}{l}\text { High elastic and tensile } \\
\text { strength and thermally stable }\end{array}$ & [212] \\
\hline Cellulose, poly(lactic acid) & $\begin{array}{l}\text { Nano Nevin polymer co. } \\
\text { (Iran) }\end{array}$ & Solution casting method & $21 \mathrm{~nm}$ & $\begin{array}{l}\text { High degradation } \\
\text { temperature, thermal stability, } \\
\text { and crystallinity }\end{array}$ & [213] \\
\hline $\begin{array}{l}\text { Polyethene oxide, cellulose } \\
\text { nanocrystal }\end{array}$ & $\begin{array}{l}\text { Microcrystalline cellulose } \\
\text { (commercially obtained) }\end{array}$ & $\begin{array}{l}\text { Acid hydrolysis, } \\
\text { high-pressure } \\
\text { homogenization, } \\
\text { electrospinning }\end{array}$ & $149 \pm 49 \mathrm{~nm}$ & $\begin{array}{c}\text { High glass transition } \\
\text { temperature and elongation at } \\
\text { break }\end{array}$ & [215] \\
\hline Cellulose, copper $\left(\mathrm{Cu}^{2+}\right)$ & $\begin{array}{c}\text { Cellulose sludge } \\
\text { (commercially obtained) }\end{array}$ & $\begin{array}{l}\text { Mechanical treatment, } \\
\text { TEMPO-mediated } \\
\text { oxidation }\end{array}$ & $15-40 \mathrm{~nm}$ & $\begin{array}{c}\text { Enhanced adsorption capacity } \\
\text { of } \mathrm{Cu}^{2+} \text {, wettability, and } \\
\text { hydrophilicity }\end{array}$ & [216] \\
\hline
\end{tabular}

Table 7 presents some filler effects on the $\mathrm{CO}_{2}$ separation performance in MMMs, and it establishes that the filler compatibility with the polymer matrix was owing to their small particle sizes. Also, the transport of $\mathrm{CO}_{2}$ was facilitated because the polymer chains' free volume and packing were influenced by the fillers.

Table 7. MMM performances for $\mathrm{CO}_{2}$ separation based on filler effects [32].

\begin{tabular}{|c|c|c|c|c|c|c|c|c|}
\hline Organic Filler & $\begin{array}{l}\text { Particle Size } \\
\text { (nm) }\end{array}$ & $\begin{array}{l}\text { Loading } \\
(w t \%)\end{array}$ & Polymer & $\begin{array}{l}\text { Feed } \\
\text { Gas }\end{array}$ & $\begin{array}{l}\text { Operation } \\
\text { Conditions }\end{array}$ & $\begin{array}{c}\mathrm{CO}_{2} \\
\text { Permeability } \\
\times 10^{14} / \mathrm{mol} \cdot \mathrm{m} \cdot \mathrm{m}^{-2} \cdot \mathrm{s}\end{array}$ & $\begin{array}{c}\mathrm{CO}_{2} / \mathrm{CH}_{4} \\
\text { Selectivity }\end{array}$ & Ref. \\
\hline $\begin{array}{c}\text { Polyaniline } \\
\text { nanosheet }\end{array}$ & $\begin{array}{l}\text { Thickness: } \\
\text { 40-60 }\end{array}$ & 17 & Poly(vinylamine) & Pure gas & $\begin{array}{c}25^{\circ} \mathrm{C}, 0.11 \\
\mathrm{MPa}, \text { in } \\
\text { humidified } \\
\text { state }\end{array}$ & $40.20 \times l^{b}$ & $12-20$ & [217] \\
\hline $\begin{array}{l}\text { Polyaniline } \\
\text { nanorod }\end{array}$ & $\begin{array}{l}\text { Diameter: } 50 \\
\text { Length: } 160\end{array}$ & 17 & Poly(vinylamine) & Pure gas & $\begin{array}{c}25^{\circ} \mathrm{C}, 0.11 \\
\mathrm{MPa}, \text { in } \\
\text { humidified } \\
\text { state }\end{array}$ & $53.67^{b}$ & $18-25$ & [218] \\
\hline Nanohydrogels & $\sim 250$ & $5,10,15,20$ & Matrimid $^{\circledR}$ & Pure gas & $\begin{array}{c}30^{\circ} \mathrm{C}, 0.2 \mathrm{MPa}, \\
\text { in } \\
\text { humidified } \\
\text { state }\end{array}$ & $4.56-9.31$ & $52-61$ & [219] \\
\hline $\begin{array}{l}\text { Carboxylic } \\
\text { acid nanogels }\end{array}$ & 400 & $5,10,15,20,30$ & $\operatorname{Pebax}^{\circledR}$ & Pure gas & $\begin{array}{c}25^{\circ} \mathrm{C}, 0.2 \mathrm{MPa}, \\
\text { in } \\
\text { humidified } \\
\text { state }\end{array}$ & $29.82-67.87$ & $19-33$ & [220] \\
\hline PEGSS $^{\text {a }}$ & $350-420$ & 20 & Matrimid $^{\circledR}$ & Pure gas & $30^{\circ} \mathrm{C}, 0.1 \mathrm{MPa}$ & 0.28 & 50.29 & [221] \\
\hline $\begin{array}{l}\text { Hypercrosslinked } \\
\text { polystyrene }\end{array}$ & 55 & 16.67 & PIM-1 & Pure gas & $25^{\circ} \mathrm{C}, 0.2 \mathrm{MPa}$ & 334.06 & 20.27 & [222] \\
\hline $\begin{array}{l}\text { Microfibrillated } \\
\text { cellulose }\end{array}$ & $\begin{array}{l}\text { Diameter: } \\
5-15\end{array}$ & $0-4$ & Polyvinylamine & $\begin{array}{l}\text { Mixed } \\
\text { gas }\end{array}$ & $\begin{array}{l}35^{\circ} \mathrm{C} \\
8 \text { bar }\end{array}$ & 13.00 & 410 & [223] \\
\hline Nanocellulose & $\begin{array}{c}\text { Length: } 130 \pm \\
67 \\
\text { Width: } 15.9 \pm \\
1.8\end{array}$ & $0.5,1,1.5,2$ & PSF & $\begin{array}{l}\text { Mixed } \\
\text { gas }\end{array}$ & $\begin{array}{l}25^{\circ} \mathrm{C} \\
8 \text { bar }\end{array}$ & 45.07 & 29 & [223] \\
\hline
\end{tabular}

a PEGSS: poly(ethylene glycol)-containing polymeric submicrospheres. ${ }^{\mathrm{b}}$ Permeability is calculated by permeance multiplied by the separation layer thickness, $l$ : the separation layer thickness, $\mu \mathrm{m}$.

Table 8 shows the performance results of the fabricated mixed matrix membranes. Pretreated lignocellulosic biomass-based filler was loaded into the polyetherimide (PEI) matrix. A combination of physical and chemical pretreatment techniques was used to obtain a functionalized filler. The powder 
X-ray diffraction showed a decrease in its crystallinity. In almost all cases, $\mathrm{CO}_{2}$ permeability increase was more evident than that of $\mathrm{CH}_{4}$. The Langmuir model-governed transport mechanism ensures the saturation of the free volume due to the $\mathrm{CO}_{2}$ and $\mathrm{CH}_{4}$ gases' kinetic diameters.

Table 8. Biomass-based filler loading effects on membrane performance.

\begin{tabular}{cccc}
\hline \multirow{2}{*}{ Filler Loading (wt $\%)$} & \multirow{2}{*}{ Selectivity } \\
\cline { 2 - 3 } & $\mathbf{C O}_{\mathbf{2}}$ Permeability & $\mathbf{C H}_{\mathbf{4}}$ Permeability & \\
\hline 0.00 & 1.25 & 0.10 & 23 \\
0.25 & 1.60 & 0.10 & 32 \\
0.50 & 1.80 & 0.05 & 43 \\
0.75 & - & - & - \\
1.00 & 1.75 & 0.05 & 40 \\
\hline
\end{tabular}

GPU: gas permeance units. Source: Reference [224].

In contrast, the transport mechanism will be governed by Henry's mode whenever $\mathrm{CH}_{4}$ permeability is favored over $\mathrm{CO}_{2}$, due to gas-polymer interaction increase and larger molecules being easily condensable. The pure PEI membrane shows low permeance and selectivity compared to after the filler was incorporated. However, $0.5 \mathrm{wt} \%$ filler loading results in the best permeability-selectivity performance. $\mathrm{n}$ The permeability-selectivity decrease recorded for $1 \mathrm{wt} \%$ loading can be attributed to less filler dispersion, and this can be resolved during doping preparation by including the sonication step because that effect is attributed to the dispersed phase clogging of the interface of the two phases. Considerations would be given to the shape and size of the particles and the preparation protocols.

Also, Wu et al. [225] worked on $\mathrm{CO}_{2}$ separation by incorporating biocellulose nanofiber (additive) into polymeric membranes. A homogeneous composite membrane solution was obtained by speed coating the additive using the spin coating method and oven drying of the membranes for half an hour at $105^{\circ} \mathrm{C}$. The results showed that increasing polymeric solution concentration resulted in increasing the thickness of the membranes. The performance (permeability and selectivity) for $3 \mathrm{wt} \%$ loadings of the additive was chosen as the best. Zhang et al. [226] reported 139 barrer $\mathrm{CO}_{2}$ permeability from composite membranes with incorporated cellulose nanofibrils, adopting chemical pretreatments to enhance the chemical bonding for high performance.

As shown in Table 9 [36], it was posited that at $5 \mathrm{wt} \%$, permeability was higher than at $2 \mathrm{wt} \%$ loadings on polysulfone membranes because it was more amorphous, which was further confirmed by the XRD results. Although, some of the selectivity results are not in line with established trends from the Robeson upper bound curve: to have selectivity increasing as permeability decreases. The upper bound trend shows a gradual decline in permselectivity. The addition of $2 \mathrm{wt} \%$ Lignocellulosic biomass (LCB) to the polymer matrix increases the selectivity, which then started decreasing as loading increased from 5 to $10 \mathrm{wt} \%$. In general, the simultaneous decrease in permeability and selectivity can be attributed to polar and nonpolar gases being separated based on the competitive sorption that favors $\mathrm{CO}_{2}$ due to its polarity, which is one of the expected setbacks from the separation of gases with close molecular diameters. $\mathrm{CO}_{2}$ is a polar gas molecule, while $\mathrm{CH}_{4}$ is a nonpolar gas molecule. Lastly, Venturi et al. [227] used a combination of mechanical and enzymatic pretreatment techniques to prepare nanofibrillated cellulose and incorporate it into polyinylamine (PVAm) to fabricate composite membranes. Values of 135 and 187 barrer were reported for $\mathrm{CO}_{2} / \mathrm{CH}_{4}$ ideal selectivity and $\mathrm{CO}_{2}$ permeability, respectively. 
Table 9. Permselectivity of pretreated Lignocellulosic biomass (LCB) (date pits) loading on $\mathrm{CO}_{2}$ separation.

\begin{tabular}{cccc}
\hline \multirow{2}{*}{ LCB in Samples (wt\%) } & \multicolumn{2}{c}{ Permeance (GPU) at $\mathbf{1 0}$ bar and $\mathbf{3 5}{ }^{\circ} \mathbf{C}$} & \multirow{2}{*}{ Selectivity } \\
\cline { 2 - 3 } & $\mathbf{C O}_{\mathbf{2}}$ Permeability & $\mathbf{C H}_{\mathbf{4}}$ Permeability & \\
\hline 0 & 240.292 & 318.229 & 0.755 \\
2 & 13.957 & 11.957 & 1.261 \\
5 & 94.949 & 115.697 & 0.821 \\
10 & 445.658 & 705.246 & 0.632 \\
\hline
\end{tabular}

LCB: Lignocellulosic biomass.

Finally, since the lignocellulose biomass contents are natural, degradation resistance and stability can be made robust through the pretreatment techniques, which will also prevent fouling. Thus, a thorough understanding of the lignification mechanism before incorporation into the polymer matrix is vital. Prospectively, MMM fabrication by incorporating lignocellulosic biomass will be faced with some challenges. The challenges include discovering an environmentally and cost-effective benign delignification process. Furthermore, process condition optimization and improvement of existing methods for the different pretreatments' reaction mechanisms have not been thoroughly explored. Multidisciplinary collaboration among material chemists, polymer scientists, and chemical and material engineers is required. Such partnership will enhance worldwide acceptance of the development of next-generation membrane materials, looking back to 1979 when Monsanto built the first hollow-fiber polysulfone membrane separation system. The next-generation materials should be able to withstand physical ageing, plasticization, etc. to increase their consideration for industrial applications. Therefore, this review discusses the characteristics of membranes and lignocellulose biomass, including the feasibility of solubilizing lignin. Some of the common challenges include extracting or isolating cellulose and hemicellulose from several agro-based sources such as wood, straws, grasses, etc. Thus, it is imperative to carefully choose an appropriate pretreatment technique(s) for high purity, yield, and compatibility; and reducing the particle size to the nanoscale using mechanical splintering will aid the reduction of the crystallinity zone for subsequent treatments. The OH group's characteristics are fundamental to lignocellulosic biomass performance and compatibility during incorporation into the polymer matrix.

Funding: The authors acknowledge the Ministry of Higher Education (MOHE), Malaysia, under TRGS grant (Grant no.: 203/PJKIMIA/67612001, project code: TRGS/1/2018/USM/01/5/1) and USM-RUI grant (Grant no.: 1001/PJKIMIA/8014063, project code: U01631) for this review work.

Conflicts of Interest: There are no conflict of interest to declare.

\section{References}

1. Dolgonosov, B.M. Knowledge production and world population dynamics. Technol. Forecast. Soc. Chang. 2016, 103, 127-141. [CrossRef]

2. Deryng, D.; Elliott, J.; Folberth, C.; Müller, C.; Pugh, T.A.M.; Boote, K.J.; Conway, D.; Ruane, A.C.; Gerten, D.; Jones, J.W.; et al. Regional disparities in the beneficial effects of rising $\mathrm{CO}_{2}$ concentrations on crop water productivity. Nat. Clim. Chang. 2016, 6, 786-790. [CrossRef]

3. Kuroyanagi, T.; Yasuba, K.-I.; Higashide, T.; Iwasaki, Y.; Takaichi, M. Efficiency of carbon dioxide enrichment in an unventilated greenhouse. Biosyst. Eng. 2014, 119, 58-68. [CrossRef]

4. Amusa, A.A.; Ahmad, A.L.; Adewole, J.K. A review on recent developments and progress in natural gas processing and separating using nanoparticles incorporated membranes. Soc. Pet. Eng. J. 2018, 1-36. [CrossRef]

5. Global Monitoring Laboratory. Carbon Cycle Greenhouse Gases. 2019. Available online: https://www.esrl. noaa.gov/gmd/ccgg/trends/gl_trend.html (accessed on 12 June 2020). 
6. BP Energy Outlook 2019 Edition. Available online: https://www.bp.com/content/dam/bp/business-sites/ en/global/corporate/pdfs/energy-economics/energy-outlook/bp-energy-outlook-2019.pdf (accessed on 13 June 2020).

7. Lin, B.; Raza, M.Y. Analysis of energy security indicators and $\mathrm{CO}_{2}$ emissions. A case from a developing economy. Energy 2020, 200, 117575. [CrossRef]

8. Li, S.; Zhou, C.; Wang, S. Does modernization affect carbon dioxide emissions? A panel data analysis. Sci. Total Environ. 2019, 663, 426-435. [CrossRef]

9. Gao, Y.; Gao, X.; Zhang, X. The $2{ }^{\circ} \mathrm{C}$ Global Temperature Target and the Evolution of the Long-Term Goal of Addressing Climate Change-From the United Nations Framework Convention on Climate Change to the Paris Agreement. Engineering 2017, 3, 272-278. [CrossRef]

10. Bauer, A.; Menrad, K. Standing up for the Paris Agreement: Do global climate targets influence individuals' greenhouse gas emissions? Environ. Sci. Policy 2019, 99, 72-79. [CrossRef]

11. Shea, M.M.; Thornton, T.F. Tracing country commitment to Indigenous peoples in the UN Framework Convention on Climate Change. Glob. Environ. Chang. 2019, 58, 101973. [CrossRef]

12. Faramawy, S.; Zaki, T.; Sakr, A.A.-E. Natural gas origin, composition, and processing: A review. J. Nat. Gas Sci. Eng. 2016, 34, 34-54. [CrossRef]

13. Alcheikhhamdon, Y.; Hoorfar, M. Natural Gas Quality Enhancement: A Review of the Conventional Treatment Processes, and the Industrial Challenges Facing Emerging Technologies; Elsevier: Amsterdam, The Netherlands, 2016; Volume 34, pp. 689-701.

14. Yang, H.; Fan, S.; Lang, X.; Wang, Y.; Nie, J. Economic comparison of three gas separation technologies for $\mathrm{CO}_{2}$ capture from power plant flue gas. Chin. J. Chem. Eng. 2011, 19, 615-620. [CrossRef]

15. Salvinder, K.M.S.; Zabiri, H.; Taqvi, S.A.; Ramasamy, M.; Isa, F.; Rozali, N.E.M.; Suleman, H.; Maulud, A.; Shariff, A.M. An overview on control strategies for $\mathrm{CO}_{2}$ capture using absorption/stripping system. Chem. Eng. Res. Des. 2019, 147, 319-337. [CrossRef]

16. Koronaki, I.P.; Prentza, L.; Papaefthimiou, V. Modeling of $\mathrm{CO}_{2}$ capture via chemical absorption processes-An extensive literature review. Renew. Sustain. Energy Rev. 2015, 50, 547-566. [CrossRef]

17. Zhao, B.; Tao, W.; Zhong, M.; Su, Y.; Cui, G. Process, performance and modeling of $\mathrm{CO}_{2}$ capture by chemical absorption using high gravity: A review. Renew. Sustain. Energy Rev. 2016, 65, 44-56. [CrossRef]

18. Bernhardsen, I.M.; Knuutila, H.K. A review of potential amine solvents for $\mathrm{CO}_{2}$ absorption process: Absorption capacity, cyclic capacity and pKa. Int. J. Greenh. Gas Control 2017, 61, 27-48. [CrossRef]

19. Grande, C.A.; Roussanaly, S.; Anantharaman, R.; Lindqvist, K.; Singh, P.; Kemper, J. $\mathrm{CO}_{2}$ Capture in Natural Gas Production by Adsorption Processes. In Proceedings of the Energy Procedia; Elsevier Ltd.: Amsterdam, The Netherlands, 2017; Volume 114, pp. 2259-2264.

20. Ünveren, E.E.; Monkul, B.Ö.; Sarığlan, S..; Karademir, N.; Alper, E. Solid amine sorbents for $\mathrm{CO}_{2}$ capture by chemical adsorption: A review. Petroleum 2017, 3, 37-50. [CrossRef]

21. Abd, A.A.; Naji, S.Z.; Hashim, A.S.; Othman, M.R. Carbon dioxide removal through Physical Adsorption using Carbonaceous and non-Carbonaceous Adsorbents: A review. J. Environ. Chem. Eng. 2020, 104142. [CrossRef]

22. Sepahvand, S.; Jonoobi, M.; Ashori, A.; Gauvin, F.; Brouwers, H.J.H.; Oksman, K.; Yu, Q. A promising process to modify cellulose nanofibers for carbon dioxide $\left(\mathrm{CO}_{2}\right)$ adsorption. Carbohydr. Polym. 2020, 230, 115571. [CrossRef]

23. Adewole, J.K.; Ahmad, A.L.; Ismail, S.; Leo, C.P.; Sultan, A.S. Comparative studies on the effects of casting solvent on physico-chemical and gas transport properties of dense polysulfone membrane used for $\mathrm{CO}_{2} / \mathrm{CH}_{4}$ separation. J. Appl. Polym. Sci. 2015, 132, 1-10. [CrossRef]

24. Chu, Y.; Lindbråthen, A.; Lei, L.; He, X.; Hillestad, M. Mathematical modeling and process parametric study of $\mathrm{CO}_{2}$ removal from natural gas by hollow fiber membranes. Chem. Eng. Res. Des. 2019, 148, 45-55. [CrossRef]

25. Jiamjirangkul, P.; Inprasit, T.; Intasanta, V.; Pangon, A. Metal organic framework-integrated chitosan/poly(vinyl alcohol) (PVA) nanofibrous membrane hybrids from green process for selective $\mathrm{CO}_{2}$ capture and filtration. Chem. Eng. Sci. 2020, 221, 115650. [CrossRef]

26. Qazi, S.; Gómez-Coma, L.; Albo, J.; Druon-Bocquet, S.; Irabien, A.; Sanchez-Marcano, J. CO 2 capture in a hollow fiber membrane contactor coupled with ionic liquid: Influence of membrane wetting and process parameters. Sep. Purif. Technol. 2020, 233, 115986. [CrossRef] 
27. Song, C.; Liu, Q.; Deng, S.; Li, H.; Kitamura, Y. Cryogenic-based $\mathrm{CO}_{2}$ capture technologies: State-of-the-art developments and current challenges. Renew. Sustain. Energy Rev. 2019, 101, 265-278. [CrossRef]

28. Yousef, A.M.; El-Maghlany, W.M.; Eldrainy, Y.A.; Attia, A. New approach for biogas purification using cryogenic separation and distillation process for $\mathrm{CO}_{2}$ capture. Energy 2018, 156, 328-351. [CrossRef]

29. Yousef, A.M.; El-Maghlany, W.M.; Eldrainy, Y.A.; Attia, A. Upgrading biogas to biomethane and liquid $\mathrm{CO}_{2}$ : A novel cryogenic process. Fuel 2019, 251, 611-628. [CrossRef]

30. Wang, H.; Fan, M.; Zhang, Z.; Hao, J.; Wang, C. Control of cryogenic extractive distillation process for separating $\mathrm{CO}_{2}-\mathrm{C}_{2} \mathrm{H}_{6}$ azeotrope. Comput. Chem. Eng. 2019, 128, 384-391. [CrossRef]

31. Bernardo, P.; Drioli, E.; Golemme, G. Membrane gas separation: A review/state of the art. Ind. Eng. Chem. Res. 2009, 48, 4638-4663. [CrossRef]

32. Wang, M.; Wang, Z.; Zhao, S.; Wang, J.; Wang, S. Recent advances on mixed matrix membranes for $\mathrm{CO}_{2}$ separation. Chin. J. Chem. Eng. 2017, 25, 1581-1597. [CrossRef]

33. Han, Y.; Ho, W.S.W. Recent advances in polymeric membranes for $\mathrm{CO}_{2}$ capture. Chin. J. Chem. Eng. 2018, 26, 2238-2254. [CrossRef]

34. Hafis, Z.M.; Shafie, M.; Ahmad, A.L.; Siew, A.; Low, C.; Rode, S.; Belaissaoui, B. Lithium chloride ( $\mathrm{LiCl}$ )-modified polyethersulfone (PES) substrate surface pore architectures on thin poly(dimethylsiloxane) (PDMS) dense layer formation and the composite membrane's performance in gas separation. RSC Adv. 2020, 10, 9500-9511. [CrossRef]

35. Chuah, C.Y.; Goh, K.; Yang, Y.; Gong, H.; Li, W.; Karahan, H.E.; Guiver, M.D.; Wang, R.; Bae, T.H. Harnessing filler materials for enhancing biogas separation membranes. Chem. Rev. 2018, 118, 8655-8769. [CrossRef] [PubMed]

36. Adewole, J.K. Transport properties of gases through integrally skinned asymmetric composite membranes prepared from date pit powder and polysulfone. J. Appl. Polym. Sci. 2016, 133, 1-8. [CrossRef]

37. Ahmad, A.L.; Adewole, J.K.; Ismail, S.B.; Peng, L.C.; Sultan, A.S. Membrane Separation of $\mathrm{CO}_{2}$ from Natural Gas: A State-of-the-Art Review on Material Development. Defect Diffus. Forum 2013, 333, 135-147. [CrossRef]

38. Rezakazemi, M.; Sadrzadeh, M.; Matsuura, T. Thermally stable polymers for advanced high-performance gas separation membranes. Prog. Energy Combust. Sci. 2018, 66, 1-41. [CrossRef]

39. González-Díaz, M.O.; Cetina-Mancilla, E.; Sulub-Sulub, R.; Montes-Luna, A.; Olvera, L.I.; Zolotukhin, M.G.; Cárdenas, J.; Aguilar-Vega, M. Novel fluorinated aromatic polymers with ether-bond-free aryl backbones for pure and mixed gas separation. J. Memb. Sci. 2020, 606, 118114. [CrossRef]

40. Usman, M.; Ahmed, A.; Yu, B.; Peng, Q.; Shen, Y.; Cong, H. A review of different synthetic approaches of amorphous intrinsic microporous polymers and their potential applications in membrane-based gases separation. Eur. Polym. J. 2019, 120, 109262. [CrossRef]

41. Chong, K.C.; Lai, S.O.; Thiam, H.S.; Teoh, H.C.; Heng, S.L. Recent Progress of Oxygen/Nitrogen Separation Using Memebrane Technology. J. Eng. Sci. Technol. 2016, 11, 1016-1030.

42. Liguori, S.; Kian, K.; Buggy, N.; Anzelmo, B.H.; Wilcox, J. Opportunities and Challenges of Low-Carbon Hydrogen via Metallic Membranes. Prog. Energy Combust. Sci. 2020, 80, 100851. [CrossRef]

43. Meinema, H.A.; Dirrix, R.W.J.; Brinkman, H.W.; Terpstra, R.A.; Jekerle, J.; Kösters, P.H. Ceramic Membranes for Gas Separation-Recent Developments and State of the Art. High Perform. Ceram. 2005, 54, 86-91.

44. Mansoori, S.; Davarnejad, R.; Matsuura, T.; Ismail, A.F. Membranes Based on Non-Synthetic (Natural) Polymers for Wastewater Treatment; Elsevier Ltd.: Amsterdam, The Netherlands, 2020; Volume 84, ISBN 9886341734.

45. Al-Saffar, H.B.; Ozturk, B.; Hughes, R. A comparison of porous and non-porous gas-liquid membrane contactors for gas separation. Chem. Eng. Res. Des. 1997, 75, 685-692. [CrossRef]

46. Xia, Q.C.; Liu, M.L.; Cao, X.L.; Wang, Y.; Xing, W.; Sun, S.P. Structure design and applications of dual-layer polymeric membranes. J. Memb. Sci. 2018, 562, 85-111. [CrossRef]

47. Koros, W.J. Membrane Handbook; Van Nostrand Reinhold Company: New York, NY, USA, 1995; Volume 99, ISBN 9781461365754.

48. Han, Y.; Salim, W.; Chen, K.K.; Wu, D.; Ho, W.S.W. Field trial of spiral-wound facilitated transport membrane module for $\mathrm{CO}_{2}$ capture from flue gas. J. Memb. Sci. 2019, 575, 242-251. [CrossRef]

49. Salim, W.; Vakharia, V.; Chen, Y.; Wu, D.; Han, Y.; Ho, W.S.W. Fabrication and field testing of spiral-wound membrane modules for $\mathrm{CO}_{2}$ capture from flue gas. J. Memb. Sci. 2018, 556, 126-137. [CrossRef]

50. Chen, K.K.; Salim, W.; Han, Y.; Wu, D.; Ho, W.S.W. Fabrication and scale-up of multi-leaf spiral-wound membrane modules for $\mathrm{CO}_{2}$ capture from flue gas. J. Memb. Sci. 2020, 595, 117504. [CrossRef] 
51. Gu, B.; Kim, D.Y.; Kim, J.H.; Yang, D.R. Mathematical model of flat sheet membrane modules for FO process: Plate-and-frame module and spiral-wound module. J. Memb. Sci. 2011, 379, 403-415. [CrossRef]

52. Ricardo, A.R.; Velizarov, S.; Crespo, J.G.; Reis, M.A.M. Validation of the ion-exchange membrane bioreactor concept in a plate-and-frame module configuration. Process Biochem. 2012, 47, 1832-1838. [CrossRef]

53. Liu, F.; Zhang, G.; Zhang, H.; Mo, J. Performance evaluation of electrodeionization process based on ionic equilibrium with plate and frame modules. Desalination 2008, 221, 425-432. [CrossRef]

54. Ismail, A.F.; Yaacob, N. Performance of treated and untreated asymmetric polysulfone hollow fiber membrane in series and cascade module configurations for $\mathrm{CO}_{2} / \mathrm{CH}_{4}$ gas separation system. J. Memb. Sci. 2006, 275, 151-165. [CrossRef]

55. Mourgues, A.; Sanchez, J. Theoretical analysis of concentration polarization in membrane modules for gas separation with feed inside the hollow-fibers. J. Memb. Sci. 2005, 252, 133-144. [CrossRef]

56. Sugiyama, T.; Miyahara, N.; Tanaka, M.; Munakata, K.; Yamamoto, I. A simulation model for transient response of a gas separation module using a hollow fiber membrane. Fusion Eng. Des. 2011, 86, 2743-2746. [CrossRef]

57. Lee, H.J.; Park, Y.G.; Kim, M.K.; Lee, S.H.; Park, J.H. Study on $\mathrm{CO}_{2}$ absorption performance of lab-scale ceramic hollow fiber membrane contactor by gas/liquid flow direction and module design. Sep. Purif. Technol. 2019, 220, 189-196. [CrossRef]

58. Matsumiya, N.; Teramoto, M.; Kitada, S.; Matsuyama, H. Evaluation of energy consumption for separation of $\mathrm{CO}_{2}$ in flue gas by hollow fiber facilitated transport membrane module with permeation of amine solution. Sep. Purif. Technol. 2005, 46, 26-32. [CrossRef]

59. Katoh, T.; Tokumura, M.; Yoshikawa, H.; Kawase, Y. Dynamic simulation of multicomponent gas separation by hollow-fiber membrane module: Nonideal mixing flows in permeate and residue sides using the tanks-in-series model. Sep. Purif. Technol. 2011, 76, 362-372. [CrossRef]

60. Dutczak, S.M.; Luiten-Olieman, M.W.J.; Zwijnenberg, H.J.; Bolhuis-Versteeg, L.A.M.; Winnubst, L.; Hempenius, M.A.; Benes, N.E.; Wessling, M.; Stamatialis, D. Composite capillary membrane for solvent resistant nanofiltration. J. Memb. Sci. 2011, 372, 182-190. [CrossRef]

61. Buysse, C.; Kovalevsky, A.; Snijkers, F.; Buekenhoudt, A.; Mullens, S.; Luyten, J.; Kretzschmar, J.; Lenaerts, S. Fabrication and oxygen permeability of gastight, macrovoid-free $\mathrm{Ba} 0.5 \mathrm{Sr} 0.5 \mathrm{Co} 0.8 \mathrm{Fe} 0.2 \mathrm{O} 3-\delta$ capillaries for high temperature gas separation. J. Memb. Sci. 2010, 359, 86-92. [CrossRef]

62. Bonyadi, S.; Mackley, M. The development of novel micro-capillary film membranes. J. Memb. Sci. 2012, 389, 137-147. [CrossRef]

63. Middelkoop, V.; Chen, H.; Michielsen, B.; Jacobs, M.; Syvertsen-Wiig, G.; Mertens, M.; Buekenhoudt, A.; Snijkers, F. Development and characterisation of dense lanthanum-based perovskite oxygen-separation capillary membranes for high-temperature applications. J. Memb. Sci. 2014, 468, 250-258. [CrossRef]

64. Teramoto, M.; Kitada, S.; Ohnishi, N.; Matsuyama, H.; Matsumiya, N. Separation and concentration of $\mathrm{CO}_{2}$ by capillary-type facilitated transport membrane module with permeation of carrier solution. J. Memb. Sci. 2004, 234, 83-94. [CrossRef]

65. Tawalbeh, M.; Tezel, F.H.; Al-Ismaily, M.; Kruczek, B. Highly permeable tubular silicalite-1 membranes for $\mathrm{CO}_{2}$ capture. Sci. Total Environ. 2019, 676, 305-320. [CrossRef]

66. Sazali, N.; Salleh, W.N.W.; Ismail, A.F.; Ismail, N.H.; Yusof, N.; Aziz, F.; Jaafar, J.; Kadirgama, K. Influence of intermediate layers in tubular carbon membrane for gas separation performance. Int. J. Hydrogen Energy 2019, 44, 20914-20923. [CrossRef]

67. Nian, P.; Liu, H.; Zhang, X. Bottom-up fabrication of two-dimensional Co-based zeolitic imidazolate framework tubular membranes consisting of nanosheets by vapor phase transformation of Co-based gel for $\mathrm{H}_{2} / \mathrm{CO}_{2}$ separation. J. Memb. Sci. 2019, 573, 200-209. [CrossRef]

68. Li, Y.; Ma, C.; Nian, P.; Liu, H.; Zhang, X. Green synthesis of ZIF-8 tubular membranes from a recyclable 2-methylimidazole water-solvent solution by $\mathrm{ZnO}$ nanorods self-converted strategy for gas separation. J. Memb. Sci. 2019, 581, 344-354. [CrossRef]

69. Antunes, R.; Borisevich, O.; Demange, D. Numerical analysis of $\mathrm{H}_{2} / \mathrm{He}$ gas separation experiments performed with a MFI-type tubular zeolite membrane. Chem. Eng. Res. Des. 2016, 109, 327-334. [CrossRef]

70. Kim, J.P.; Magnone, E.; Park, J.H.; Lee, Y. Oxygen production of tubular module with La0.6Sr0.4Ti0.3Fe0.7O3- $\delta$ coated Ba 0.5Sr 0.5Co 0.8Fe 0.2O 3- $\delta$ membrane. J. Memb. Sci. 2012, 403-404, 188-195. [CrossRef] 
71. Latif, M.; Kasi, A.K.; Kasi, J.K.; Bokhari, M. Strengthening of alumina tubular membrane by Al support and its application for oil-in-water stable emulsion. Microelectron. Eng. 2019, 218, 111134. [CrossRef]

72. Sazali, N.; Salleh, W.N.W.; Ismail, A.F. Carbon tubular membranes from nanocrystalline cellulose blended with P84 co-polyimide for $\mathrm{H}_{2}$ and He separation. Int. J. Hydrogen Energy 2017, 42, 9952-9957. [CrossRef]

73. Zhao, Y.; Zhao, D.; Kong, C.; Zhou, F.; Jiang, T.; Chen, L. Design of thin and tubular MOFs-polymer mixed matrix membranes for highly selective separation of $\mathrm{H}_{2}$ and $\mathrm{CO}_{2}$. Sep. Purif. Technol. 2019, 220, 197-205. [CrossRef]

74. Galizia, M.; Chi, W.S.; Smith, Z.P.; Merkel, T.C.; Baker, R.W.; Freeman, B.D. 50th Anniversary Perspective: Polymers and Mixed Matrix Membranes for Gas and Vapor Separation: A Review and Prospective Opportunities. Macromolecules 2017, 50, 7809-7843. [CrossRef]

75. Smit, B.; Reimer, J.A.; Oldenburg, C.M.; Bourg, I.C. Introduction to Carbon Capture and Sequestration; Imperial College Press: London, UK, 2014; ISBN 9781783263271.

76. Robeson, L. Polymer membranes for gas separation. Curr. Opin. Solid State Mater. Sci. 1999, 4, 549-552. [CrossRef]

77. Robeson, L.M. The upper bound revisited. J. Memb. Sci. 2008, 320, 390-400. [CrossRef]

78. Comesaña-Gándara, B.; Chen, J.; Bezzu, C.G.; Carta, M.; Rose, I.; Ferrari, M.C.; Esposito, E.; Fuoco, A.; Jansen, J.C.; McKeown, N.B. Redefining the Robeson upper bounds for $\mathrm{CO}_{2} / \mathrm{CH}_{4}$ and $\mathrm{CO}_{2} / \mathrm{N}_{2}$ separations using a series of ultrapermeable benzotriptycene-based polymers of intrinsic microporosity. Energy Environ. Sci. 2019, 12, 2733-2740. [CrossRef]

79. Baker, R.W.; Low, B.T. Gas Separation Membrane Materials: A Perspective. Macromolecules 2014, 47, 6999-7013. [CrossRef]

80. Adewole, J.K.K.; Ahmad, A.L.L.; Ismail, S.; Leo, C.P.P. Current challenges in membrane separation of $\mathrm{CO}_{2}$ from natural gas: A review. Int. J. Greenh. Gas Control 2013, 17, 46-65. [CrossRef]

81. Khan, A.L.; Li, X.; Vankelecom, I.F.J. SPEEK/Matrimid blend membranes for $\mathrm{CO}_{2}$ separation. J. Memb. Sci. 2011, 380, 55-62. [CrossRef]

82. Lee, W.H.; Seong, J.G.; Hu, X.; Lee, Y.M. Recent progress in microporous polymers from thermally rearranged polymers and polymers of intrinsic microporosity for membrane gas separation: Pushing performance limits and revisiting trade-off lines. J. Polym. Sci. 2020, 5, pol.20200110. [CrossRef]

83. Raza, A.; Farrukh, S.; Hussain, A.; Khan, I.U.; Noor, T.; Othman, M.H.D.; Yousaf, M.F. Development of high performance amine functionalized zeolitic imidazolate framework (ZIF-8)/cellulose triacetate mixed matrix membranes for $\mathrm{CO}_{2} / \mathrm{CH}_{4}$ separation. Int. J. Energy Res. 2020, 44, 7989-7999. [CrossRef]

84. Park, H.B.; Freeman, B.D. Gas separation properties and their applications of high permeable amorphous perfluoropolymer membranes. Memburein 2007, 17, 81-92.

85. Azizi, N.; Zarei, M.M. $\mathrm{CO}_{2} / \mathrm{CH}_{4}$ separation using prepared and characterized poly (ether-block-amide)/ZIF-8 mixed matrix membranes. Pet. Sci. Technol. 2017, 35, 869-874. [CrossRef]

86. Scholes, C.A.; Chen, G.Q.; Stevens, G.W.; Kentish, S.E. Plasticization of ultra-thin polysulfone membranes by carbon dioxide. J. Memb. Sci. 2010, 346, 208-214. [CrossRef]

87. Bhattacharya, A.; Misra, B.N. Grafting: A versatile means to modify polymers: Techniques, factors and applications. Prog. Polym. Sci. 2004, 29, 767-814. [CrossRef]

88. Li, H.; Lin, Y.; Tsui, T.Y.; Vlassak, J.J. The effect of porogen loading on the stiffness and fracture energy of brittle organosilicates. J. Mater. Res. 2009, 24, 107-116. [CrossRef]

89. Marti, N.; Quattrini, F.; Butté, A.; Morbidelli, M. Production of polymeric materials with controlled pore structure: The "reactive gelation" process. Macromol. Mater. Eng. 2005, 290, 221-229. [CrossRef]

90. Xiao, Y.; Low, B.T.; Hosseini, S.S.; Chung, T.S.; Paul, D.R. The strategies of molecular architecture and modification of polyimide-based membranes for $\mathrm{CO}_{2}$ removal from natural gas-A review. Prog. Polym. Sci. 2009, 34, 561-580. [CrossRef]

91. Scholes, C.A.; Smith, K.H.; Kentish, S.E.; Stevens, G.W. $\mathrm{CO}_{2}$ capture from pre-combustion processes-Strategies for membrane gas separation. Int. J. Greenh. Gas Control 2010, 4, 739-755. [CrossRef]

92. Yong, W.F.; Li, F.Y.; Xiao, Y.C.; Li, P.; Pramoda, K.P.; Tong, Y.W.; Chung, T.S. Molecular engineering of PIM-1/Matrimid blend membranes for gas separation. J. Memb. Sci. 2012, 407-408, 47-57. [CrossRef]

93. Ribeiro, C.P.; Freeman, B.D.; Paul, D.R. Pure- and mixed-gas carbon dioxide/ethane permeability and diffusivity in a cross-linked poly(ethylene oxide) copolymer. J. Memb. Sci. 2011, 377, 110-123. [CrossRef] 
94. Ismail, A.F.; Lai, P.Y. Effects of phase inversion and rheological factors on formation of defect-free and ultrathin-skinned asymmetric polysulfone membranes for gas separation. Sep. Purif. Technol. 2003, 33, 127-143. [CrossRef]

95. Han, J.; Lee, W.; Choi, J.M.; Patel, R.; Min, B.R. Characterization of polyethersulfone/polyimide blend membranes prepared by a dry/wet phase inversion: Precipitation kinetics, morphology and gas separation. J. Memb. Sci. 2010, 351, 141-148. [CrossRef]

96. Khan, A.L.; Li, X.; Vankelecom, I.F.J. Mixed-gas $\mathrm{CO}_{2} / \mathrm{CH}_{4}$ and $\mathrm{CO}_{2} / \mathrm{N}_{2}$ separation with sulfonated PEEK membranes. J. Memb. Sci. 2011, 372, 87-96. [CrossRef]

97. Kruczek, B.; Matsuura, T. Effect of metal substitution of high molecular weight sulfonated polyphenylene oxide membranes on their gas separation performance. J. Memb. Sci. 2000, 167, 203-216. [CrossRef]

98. Li, Y.; Chung, T.S. Highly selective sulfonated polyethersulfone (SPES)-based membranes with transition metal counterions for hydrogen recovery and natural gas separation. J. Memb. Sci. 2008, 308, 128-135. [CrossRef]

99. McKeown, N.B.; Budd, P.M. Exploitation of intrinsic microporosity in polymer-based materials. Macromolecules 2010, 43, 5163-5176. [CrossRef]

100. Du, N.; Robertson, G.P.; Dal-Cin, M.M.; Scoles, L.; Guiver, M.D. Polymers of intrinsic microporosity (PIMs) substituted with methyl tetrazole. Polymer 2012, 53, 4367-4372. [CrossRef]

101. Choi, H.S.; Jeon, H.J.; Choi, J.H.; Lee, G.H.; Kang, J.K. Tailoring open metal sites for selective capture of $\mathrm{CO}_{2}$ in isostructural metalloporphyrin porous organic networks. Nanoscale 2015, 7, 18923-18927. [CrossRef] [PubMed]

102. Zakharova, M.V.; Kleitz, F.; Fontaine, F.-G. Lewis acidity quantification and catalytic activity of Ti, Zr and Al-supported mesoporous silica. Dalt. Trans. 2017, 46, 3864-3876. [CrossRef] [PubMed]

103. Kundu, S.K.; Bhaumik, A. Novel nitrogen and sulfur rich hyper-cross-linked microporous poly-triazine-thiophene copolymer for superior $\mathrm{CO}_{2}$ capture. ACS Sustain. Chem. Eng. 2016, 4, 3697-3703. [CrossRef]

104. Lim, C.H.; Holder, A.M.; Musgrave, C.B. Mechanism of homogeneous reduction of $\mathrm{CO}_{2}$ by pyridine: Proton relay in aqueous solvent and aromatic stabilization. J. Am. Chem. Soc. 2013, 135, 142-154. [CrossRef]

105. Duque-Acevedo, M.; Belmonte-Ureña, L.J.; Cortés-García, F.J.; Camacho-Ferre, F. Agricultural waste: Review of the evolution, approaches and perspectives on alternative uses. Glob. Ecol. Conserv. 2020, 22. [CrossRef]

106. Gallo, J.M.R.; Trapp, M.A. The chemical conversion of biomass-derived saccharides: An overview. J. Braz. Chem. Soc. 2017, 28, 1586-1607. [CrossRef]

107. Zevallos Torres, L.A.; Lorenci Woiciechowski, A.; de Andrade Tanobe, V.O.; Karp, S.G.; Guimarães Lorenci, L.C.; Faulds, C.; Soccol, C.R. Lignin as a potential source of high-added value compounds: A review. J. Clean. Prod. 2020, 263, 121499. [CrossRef]

108. Bhuiyan, N.H.; Selvaraj, G.; Wei, Y.; King, J. Role of lignification in plant defense. Plant Signal. Behav. 2009, 4, 158-159. [CrossRef] [PubMed]

109. Koch, G.W.; Stillet, S.C.; Jennings, G.M.; Davis, S.D. The limits to tree height. Nature 2004, 428, 851-854. [CrossRef] [PubMed]

110. Boerjan, W.; Ralph, J.; Baucher, M. Lignin Biosynthesis. Annu. Rev. Plant Biol. 2003, 54, 519-546. [CrossRef] [PubMed]

111. Plomion, C.; Leprovost, G.; Stokes, A. Wood formation in trees. Plant Physiol. 2001, 127, 1513-1523. [CrossRef] [PubMed]

112. Himmel, M.E.; Ding, S.Y.; Johnson, D.K.; Adney, W.S.; Nimlos, M.R.; Brady, J.W.; Foust, T.D. Biomass recalcitrance: Engineering plants and enzymes for biofuels production. Science 2007, 315, 804-807. [CrossRef]

113. Li, M.; Pu, Y.; Ragauskas, A.J. Current understanding of the correlation of lignin structure with biomass recalcitrance. Front. Chem. 2016, 4, 1-8. [CrossRef]

114. Zoghlami, A.; Paës, G. Lignocellulosic Biomass: Understanding Recalcitrance and Predicting Hydrolysis. Front. Chem. 2019, 7, 874. [CrossRef]

115. Meng, X.; Pu, Y.; Yoo, C.G.; Li, M.; Bali, G.; Park, D.Y.; Gjersing, E.; Davis, M.F.; Muchero, W.; Tuskan, G.A.; et al. An In-Depth Understanding of Biomass Recalcitrance Using Natural Poplar Variants as the Feedstock. ChemSusChem 2017, 10, 139-150. [CrossRef] 
116. Novaes, E.; Osorio, L.; Drost, D.R.; Miles, B.L.; Boaventura-Novaes, C.R.D.; Benedict, C.; Dervinis, C.; Yu, Q.; Sykes, R.; Davis, M.; et al. Quantitative genetic analysis of biomass and wood chemistry of Populus under different nitrogen levels. New Phytol. 2009, 182, 878-890. [CrossRef]

117. Kirst, M.; Myburg, A.A.; De León, J.P.G.; Kirst, M.E.; Scott, J.; Sederoff, R. Coordinated genetic regulation of growth and lignin revealed by quantitative trait locus analysis of cDNA microarray data in an interspecific backcross of eucalyptus. Plant Physiol. 2004, 135, 2368-2378. [CrossRef]

118. Andersson-Gunnerås, S.; Mellerowicz, E.J.; Love, J.; Segerman, B.; Ohmiya, Y.; Coutinho, P.M.; Nilsson, P.; Henrissat, B.; Moritz, T.; Sundberg, B. Biosynthesis of cellulose-enriched tension wood in Populus: Global analysis of transcripts and metabolites identifies biochemical and developmental regulators in secondary wall biosynthesis. Plant J. 2006, 45, 144-165. [CrossRef] [PubMed]

119. Erdtman, H. Lignins: Occurrence, formation, structure and reactions, K.V. Sarkanen and C.H. Ludwig, Eds., John Wiley \& Sons, Inc., New York, 1971. 916 pp. \$35.00. J. Polym. Sci. Part B Polym. Lett. 1972, 10, 228-230. [CrossRef]

120. Robinson, J.M. Lignin, land plants, and fungi: Biological evolution affecting Phanerozoic oxygen balance. Geology 1990, 18, 607-610. [CrossRef]

121. Fernandez, J.A.; Asso-, C.P.; House, E.; Street, E.S. Nutritional ecology of the ruminant. Livest. Prod. Sci. $1995,43,179-180$.

122. Fengel, D.; Wegner, G. Wood Chemistry, Ultrastructure, Reactions; de Gruyter: Berlin, Germany, 1983; ISBN 3110120593.

123. Schaefer, D.; Steinberger, Y.; Whitford, W.G. The failure of nitrogen and lignin control of decomposition in a North American desert. Oecologia 1985, 65, 382-386. [CrossRef]

124. Kumar, B.; Bhardwaj, N.; Agrawal, K.; Chaturvedi, V.; Verma, P. Current perspective on pretreatment technologies using lignocellulosic biomass: An emerging biorefinery concept. Fuel Process. Technol. 2020, 199, 106244. [CrossRef]

125. Wang, Y.; Liu, Q.; Yan, L.; Gao, Y.; Wang, Y.; Wang, W. A novel lignin degradation bacterial consortium for efficient pulping. Bioresour. Technol. 2013, 139, 113-119. [CrossRef]

126. Wang, S.; Wang, K.; Liu, Q.; Gu, Y.; Luo, Z.; Cen, K.; Fransson, T. Comparison of the pyrolysis behavior of lignins from different tree species. Biotechnol. Adv. 2009, 27, 562-567. [CrossRef]

127. Lupoi, J.S.; Singh, S.; Parthasarathi, R.; Simmons, B.A.; Henry, R.J. Recent innovations in analytical methods for the qualitative and quantitative assessment of lignin. Renew. Sustain. Energy Rev. 2015, 49, 871-906. [CrossRef]

128. Gabrielii, I.; Gatenholm, P.; Glasser, W.G.; Jain, R.K.; Kenne, L. Separation, characterization and hydrogel-formation of hemicellulose from aspen wood. Carbohydr. Polym. 2000, 43, 367-374. [CrossRef]

129. Sun, R.C.; Fang, J.M.; Tomkinson, J. Characterization and esterification of hemicelluloses from rye straw. J. Agric. Food Chem. 2000, 48, 1247-1252. [CrossRef] [PubMed]

130. Fang, J.M.; Sun, R.C.; Tomkinson, J.; Fowler, P. Acetylation of wheat straw hemicellulose B in a new non-aqueous swelling system. Carbohydr. Polym. 2000, 41, 379-387. [CrossRef]

131. Peng, F.; Peng, P.; Xu, F.; Sun, R.C. Fractional purification and bioconversion of hemicelluloses. Biotechnol. Adv. 2012, 30, 879-903. [CrossRef] [PubMed]

132. Sunna, A.; Antranikian, G. Xylanolytic enzymes from fungi and bacteria. Crit. Rev. Biotechnol. 1997, 17, 39-67. [CrossRef] [PubMed]

133. Fundador, N.G.V.; Enomoto-Rogers, Y.; Takemura, A.; Iwata, T. Acetylation and characterization of xylan from hardwood kraft pulp. Carbohydr. Polym. 2012, 87, 170-176. [CrossRef]

134. Akais, O.C. Global Perspectives on Sustainable Forest Management; InTech: London, UK, 2012.

135. Kusema, B.T.; Murzin, D.Y. Catalytic oxidation of rare sugars over gold catalysts. Catal. Sci. Technol. 2013, 3, 297-307. [CrossRef]

136. Farhat, W.; Venditti, R.A.; Hubbe, M.; Taha, M.; Becquart, F.; Ayoub, A. A Review of Water-Resistant Hemicellulose-Based Materials: Processing and Applications. ChemSusChem 2017, 10, 305-323. [CrossRef]

137. Serra, D.O.; Richter, A.M.; Hengge, R. Cellulose as an architectural element in spatially structured escherichia coli biofilms. J. Bacteriol. 2013, 195, 5540-5554. [CrossRef]

138. Morgan, J.L.W.; Strumillo, J.; Zimmer, J. Crystallographic snapshot of cellulose synthesis and membrane translocation. Nature 2013, 493, 181-186. [CrossRef] 
139. Abe, K.; Yano, H. Comparison of the characteristics of cellulose microfibril aggregates of wood, rice straw and potato tuber. Cellulose 2009, 16, 1017-1023. [CrossRef]

140. Beck-Candanedo, S.; Roman, M.; Gray, D.G. Effect of reaction conditions on the properties and behavior of wood cellulose nanocrystal suspensions. Biomacromolecules 2005, 6, 1048-1054. [CrossRef] [PubMed]

141. Eichhorn, S.J.; Dufresne, A.; Aranguren, M.; Marcovich, N.E.; Capadona, J.R.; Rowan, S.J.; Weder, C.; Thielemans, W.; Roman, M.; Renneckar, S.; et al. Review: Current international research into cellulose nanofibres and nanocomposites. J. Mater. Sci. 2010, 45, 1-33. [CrossRef]

142. Farooq, A.; Patoary, M.K.; Zhang, M.; Mussana, H.; Li, M.; Naeem, M.A.; Mushtaq, M.; Farooq, A.; Liu, L. Cellulose from sources to nanocellulose and an overview of synthesis and properties of nanocellulose/zinc oxide nanocomposite materials. Int. J. Biol. Macromol. 2020, 154, 1050-1073. [CrossRef] [PubMed]

143. Ferrier, W.G. The crystal and molecular structure of $\beta$-D-glucose. Acta Crystallogr. 1963, 16, $1023-1031$. [CrossRef]

144. Chu, S.S.C.; Jeffrey, G.A. The refinement of the crystal structures of $\beta$-D-glucose and cellobiose. Acta Crystallogr. Sect. B Struct. Crystallogr. Cryst. Chem. 1968, 24, 830-838. [CrossRef]

145. Kono, H.; Yunoki, S.; Shikano, T.; Fujiwara, M.; Erata, T.; Takai, M. CP/MAS 13C NMR study of cellulose and cellulose derivatives. 1. Complete assignment of the CP/MAS 13C NMR spectrum of the native cellulose. J. Am. Chem. Soc. 2002, 124, 7506-7511. [CrossRef]

146. Nishiyama, Y.; Langan, P.; Chanzy, H. Crystal structure and hydrogen-bonding system in cellulose I $\beta$ from synchrotron X-ray and neutron fiber diffraction. J. Am. Chem. Soc. 2002, 124, 9074-9082. [CrossRef]

147. Olsson, C.; Westm, G. Direct Dissolution of Cellulose: Background, Means and Applications. In Cellulose-Fundamental Aspects; InTech: London, UK, 2013; pp. 143-178.

148. Kumari, D.; Singh, R. Pretreatment of lignocellulosic wastes for biofuel production: A critical review. Renew. Sustain. Energy Rev. 2018, 90, 877-891. [CrossRef]

149. Akhtar, N.; Gupta, K.; Goyal, D.; Goyal, A. Recent advances in pretreatment technologies for efficient hydrolysis of lignocellulosic biomass. Environ. Prog. Sustain. Energy 2016, 35, 489-511. [CrossRef]

150. Sun, S.; Sun, S.; Cao, X.; Sun, R. The role of pretreatment in improving the enzymatic hydrolysis of lignocellulosic materials. Bioresour. Technol. 2016, 199, 49-58. [CrossRef]

151. Chen, H.; Liu, J.; Chang, X.; Chen, D.; Xue, Y.; Liu, P.; Lin, H.; Han, S. A review on the pretreatment of lignocellulose for high-value chemicals. Fuel Process. Technol. 2017, 160, 196-206. [CrossRef]

152. Nauman Aftab, M.; Iqbal, I.; Riaz, F.; Karadag, A.; Tabatabaei, M. Different Pretreatment Methods of Lignocellulosic Biomass for Use in Biofuel Production. In Biomass for Bioenergy-Recent Trends and Future Challenges; IntechOpen: London, UK, 2019; p. 24.

153. Balan, V.; Bals, B.; Chundawat, S.P.S.; Marshall, D.; Dale, B.E. Lignocellulosic biomass pretreatment using AFEX. Methods Mol. Biol. 2009, 581, 61-77. [CrossRef] [PubMed]

154. Baruah, J.; Nath, B.K.; Sharma, R.; Kumar, S.; Deka, R.C.; Baruah, D.C.; Kalita, E. Recent trends in the pretreatment of lignocellulosic biomass for value-added products. Front. Energy Res. 2018, 6, 141. [CrossRef]

155. Ji, X.J.; Huang, H.; Nie, Z.K.; Qu, L.; Xu, Q.; Tsao, G.T. Fuels and chemicals from hemicellulose sugars. Adv. Biochem. Eng. Biotechnol. 2012, 128, 199-224. [CrossRef] [PubMed]

156. Iona Capital pioneers trials of two biogas pretreatment technologies. Bioenergy Int. 2018, 3-5. Available online: https://bioenergyinternational.com/technology-suppliers/iona-capital-pioneers-trials-of-two-biogaspretreatment-technologies (accessed on 19 November 2020).

157. Barakat, A.; Mayer-Laigle, C.; Solhy, A.; Arancon, R.A.D.; De Vries, H.; Luque, R. Mechanical pretreatments of lignocellulosic biomass: Towards facile and environmentally sound technologies for biofuels production. RSC Adv. 2014, 4, 48109-48127. [CrossRef]

158. Kumar, P.; Barrett, D.M.; Delwiche, M.J.; Stroeve, P. Methods for pretreatment of lignocellulosic biomass for efficient hydrolysis and biofuel production. Ind. Eng. Chem. Res. 2009, 48, 3713-3729. [CrossRef]

159. Hendriks, A.T.W.M.; Zeeman, G. Pretreatments to enhance the digestibility of lignocellulosic biomass. Bioresour. Technol. 2009, 100, 10-18. [CrossRef] [PubMed]

160. Badiei, M.; Asim, N.; Jahim, J.M.; Sopian, K. Comparison of Chemical Pretreatment Methods for Cellulosic Biomass. APCBEE Procedia 2014, 9, 170-174. [CrossRef]

161. Xu, H.; Li, B.; Mu, X. Review of Alkali-Based Pretreatment to Enhance Enzymatic Saccharification for Lignocellulosic Biomass Conversion. Ind. Eng. Chem. Res. 2016, 55, 8691-8705. [CrossRef] 
162. Borand, M.N.; Karaosmanoğlu, F. Effects of organosolv pretreatment conditions for lignocellulosic biomass in biorefinery applications: A review. J. Renew. Sustain. Energy 2018, 10, 033104. [CrossRef]

163. Moniruzzaman, M.; Goto, M. Ionic Liquid Pretreatment of Lignocellulosic Biomass for Enhanced Enzymatic Delignification. In Advances in Biochemical Engineering/Biotechnology; Springer Science and Business Media Deutschland GmbH: Berlin/Heidelberg, Germany, 2019; Volume 168, pp. 61-77.

164. Agbor, V.B.; Cicek, N.; Sparling, R.; Berlin, A.; Levin, D.B. Biomass Pretreatment: Fundamentals toward Application. Biotechnol. Adv. 2011, 29, 675-685. [CrossRef] [PubMed]

165. Amin, F.R.; Khalid, H.; Zhang, H.; Rahman, S.; Zhang, R.; Liu, G.; Chen, C. Pretreatment methods of lignocellulosic biomass for anaerobic digestion. AMB Express 2017, 7. [CrossRef] [PubMed]

166. Liew, Y.X.; Chan, Y.J.; Manickam, S.; Chong, M.F.; Chong, S.; Tiong, T.J.; Lim, J.W.; Pan, G.T. Enzymatic pretreatment to enhance anaerobic bioconversion of high strength wastewater to biogas: A review. Sci. Total Environ. 2020, 713, 136373. [CrossRef] [PubMed]

167. Hosseini Koupaie, E.; Dahadha, S.; Bazyar Lakeh, A.A.; Azizi, A.; Elbeshbishy, E. Enzymatic pretreatment of lignocellulosic biomass for enhanced biomethane production-A review. J. Environ. Manage. 2019, 233, 774-784. [CrossRef]

168. Li, X.; Weng, J.K.; Chapple, C. Improvement of biomass through lignin modification. Plant J. 2008, 54, 569-581. [CrossRef]

169. Park, H.B.; Kamcev, J.; Robeson, L.M.; Elimelech, M.; Freeman, B.D. Maximizing the right stuff: The trade-off between membrane permeability and selectivity. Science 2017, 356, 1138-1148. [CrossRef]

170. Setiawan, W.K.; Chiang, K.Y. Silica applied as mixed matrix membrane inorganic filler for gas separation: A review. Sustain. Environ. Res. 2019, 29, 32. [CrossRef]

171. Phanthong, P.; Reubroycharoen, P.; Hao, X.; Xu, G.; Abudula, A.; Guan, G. Nanocellulose: Extraction and application. Carbon Resour. Convers. 2018, 1, 32-43. [CrossRef]

172. Prakash Menon, M.; Selvakumar, R.; Suresh Kumar, P.; Ramakrishna, S. Extraction and modification of cellulose nanofibers derived from biomass for environmental application. RSC Adv. 2017, 7, 42750-42773. [CrossRef]

173. Andrade, R.; Skurtys, O.; Osorio, F. Drop impact of gelatin coating formulated with cellulose nanofibers on banana and eggplant epicarps. LWT Food Sci. Technol. 2015, 61, 422-429. [CrossRef]

174. Cara, C.; Ruiz, E.; Ballesteros, M.; Manzanares, P.; Negro, M.J.; Castro, E. Production of fuel ethanol from steam-explosion pretreated olive tree pruning. Fuel 2008, 87, 692-700. [CrossRef]

175. Yousefi, H.; Nishino, T.; Faezipour, M.; Ebrahimi, G.; Shakeri, A. Direct fabrication of all -cellulose nanocomposite from cellulose microfibers using ionic liquid-based nanowelding. Biomacromolecules 2011, 12, 4080-4085. [CrossRef] [PubMed]

176. Kalita, E.; Nath, B.K.; Deb, P.; Agan, F.; Islam, M.R.; Saikia, K. High quality fluorescent cellulose nanofibers from endemic rice husk: Isolation and characterization. Carbohydr. Polym. 2015, 122, 308-313. [CrossRef]

177. Theng, D.; Arbat, G.; Delgado-Aguilar, M.; Vilaseca, F.; Ngo, B.; Mutjé, P. All-lignocellulosic fiberboard from corn biomass and cellulose nanofibers. Ind. Crops Prod. 2015, 76, 166-173. [CrossRef]

178. Andrade-Mahecha, M.M.; Pelissari, F.M.; Tapia-Blácido, D.R.; Menegalli, F.C. Achira as a source of biodegradable materials: Isolation and characterization of nanofibers. Carbohydr. Polym. 2015, 123, 406-415. [CrossRef]

179. Sehaqui, H.; Mautner, A.; Perez De Larraya, U.; Pfenninger, N.; Tingaut, P.; Zimmermann, T. Cationic cellulose nanofibers from waste pulp residues and their nitrate, fluoride, sulphate and phosphate adsorption properties. Carbohydr. Polym. 2016, 135, 334-340. [CrossRef]

180. Khawas, P.; Deka, S.C. Effect of modified resistant starch of culinary banana on physicochemical, functional, morphological, diffraction, and thermal properties. Int. J. Food Prop. 2017, 20, 133-150. [CrossRef]

181. Khawas, P.; Deka, S.C. Comparative Nutritional, Functional, Morphological, and Diffractogram Study on Culinary Banana (Musa ABB) Peel at Various Stages of Development. Int. J. Food Prop. 2016, 19, 2832-2853. [CrossRef]

182. Chen, W.; Yu, H.; Liu, Y.; Chen, P.; Zhang, M.; Hai, Y. Individualization of cellulose nanofibers from wood using high-intensity ultrasonication combined with chemical pretreatments. Carbohydr. Polym. 2011, 83, 1804-1811. [CrossRef] 
183. Chen, W.; Li, Q.; Cao, J.; Liu, Y.; Li, J.; Zhang, J.; Luo, S.; Yu, H. Revealing the structures of cellulose nanofiber bundles obtained by mechanical nanofibrillation via TEM observation. Carbohydr. Polym. 2015, 117, 950-956. [CrossRef] [PubMed]

184. Bettaieb, F.; Nechyporchuk, O.; Khiari, R.; Mhenni, M.F.; Dufresne, A.; Belgacem, M.N. Effect of the oxidation treatment on the production of cellulose nanofiber suspensions from Posidonia oceanica: The rheological aspect. Carbohydr. Polym. 2015, 134, 664-672. [CrossRef] [PubMed]

185. Jiang, F.; Hsieh, Y. Lo Cellulose nanocrystal isolation from tomato peels and assembled nanofibers. Carbohydr. Polym. 2015, 122, 60-68. [CrossRef]

186. Elrasheedy, A.; Nady, N.; Bassyouni, M.; El-Shazly, A. Metal Organic Framework Based Polymer Mixed Matrix Membranes: Review on Applications in Water Purification. Membranes 2019, 9, 88. [CrossRef] [PubMed]

187. O’Harra, K.E.; Kammakakam, I.; Devriese, E.M.; Noll, D.M.; Bara, J.E.; Jackson, E.M. Synthesis and performance of 6FDA-based polyimide-ionenes and composites with ionic liquids as gas separation membranes. Membranes 2019, 9, 79. [CrossRef]

188. Wang, J.; Lu, X.; Ng, P.F.; Lee, K.I.; Fei, B.; Xin, J.H.; Wu, J. yong Polyethylenimine coated bacterial cellulose nanofiber membrane and application as adsorbent and catalyst. J. Colloid Interface Sci. 2015, 440, 32-38. [CrossRef]

189. Hu, W.; Chen, S.; Yang, Z.; Liu, L.; Wang, H. Flexible electrically conductive nanocomposite membrane based on bacterial cellulose and polyaniline. J. Phys. Chem. B 2011, 115, 8453-8457. [CrossRef]

190. Lin, Z.; Guan, Z.; Huang, Z. New bacterial cellulose/polyaniline nanocomposite film with one conductive side through constrained interfacial polymerization. Ind. Eng. Chem. Res. 2013, 52, 2869-2874. [CrossRef]

191. Hobzova, R.; Duskova-Smrckova, M.; Michalek, J.; Karpushkin, E.; Gatenholm, P. Methacrylate hydrogels reinforced with bacterial cellulose. Polym. Int. 2012, 61, 1193-1201. [CrossRef]

192. Kramer, F.; Klemm, D.; Schumann, D.; Heßler, N.; Wesarg, F.; Fried, W.; Stadermann, D. Nanocellulose Polymer Composites as Innovative Pool for (Bio)Material Development. Macromol. Symp. 2006, 244, 136-148. [CrossRef]

193. Nogi, M.; Yano, H. Transparent nanocomposites based on cellulose produced by bacteria offer potential innovation in the electronics device industry. Adv. Mater. 2008, 20, 1849-1852. [CrossRef]

194. Millon, L.E.; Wan, W.K. The polyvinyl alcohol-bacterial cellulose system as a new nanocomposite for biomedical applications. J. Biomed. Mater. Res. Part B Appl. Biomater. 2006, 79, 245-253. [CrossRef] [PubMed]

195. Zhao, J.; Xu, H.; Fang, J.; Yin, J. Synthesis and characterization of novel aromatic polyamides via Yamazaki-Higashi phosphorylation method. J. Appl. Polym. Sci. 2012, 126, 244-252. [CrossRef]

196. Brown, E.E.; Laborie, M.P.G. Bioengineering bacterial cellulose/poly(ethylene oxide) nanocomposites. Biomacromolecules 2007, 8, 3074-3081. [CrossRef] [PubMed]

197. Sato, A.; Kabusaki, D.; Okumura, H.; Nakatani, T.; Nakatsubo, F.; Yano, H. Surface modification of cellulose nanofibers with alkenyl succinic anhydride for high-density polyethylene reinforcement. Compos. Part A Appl. Sci. Manuf. 2016, 83, 72-79. [CrossRef]

198. Ding, W.; Chu, R.K.M.; Mark, L.H.; Park, C.B.; Sain, M. Non-isothermal crystallization behaviors of poly(lactic acid)/cellulose nanofiber composites in the presence of $\mathrm{CO}_{2}$. Eur. Polym. J. 2015, 71, 231-247. [CrossRef]

199. Nasri-Nasrabadi, B.; Mehrasa, M.; Rafienia, M.; Bonakdar, S.; Behzad, T.; Gavanji, S. Porous starch/cellulose nanofibers composite prepared by salt leaching technique for tissue engineering. Carbohydr. Polym. 2014, 108, 232-238. [CrossRef]

200. Benhamou, K.; Kaddami, H.; Magnin, A.; Dufresne, A.; Ahmad, A. Bio-based polyurethane reinforced with cellulose nanofibers: A comprehensive investigation on the effect of interface. Carbohydr. Polym. 2015, 122, 202-211. [CrossRef]

201. Prakobna, K.; Terenzi, C.; Zhou, Q.; Furó, I.; Berglund, L.A. Core-shell cellulose nanofibers for biocomposites-Nanostructural effects in hydrated state. Carbohydr. Polym. 2015, 125, 92-102. [CrossRef]

202. Babaee, M.; Jonoobi, M.; Hamzeh, Y.; Ashori, A. Biodegradability and mechanical properties of reinforced starch nanocomposites using cellulose nanofibers. Carbohydr. Polym. 2015, 132, 1-8. [CrossRef]

203. Aouada, F.A.; De Moura, M.R.; Orts, W.J.; Mattoso, L.H.C. Preparation and characterization of novel micro- and nanocomposite hydrogels containing cellulosic fibrils. J. Agric. Food Chem. 2011, 59, 9433-9442. [CrossRef] [PubMed] 
204. Tamahkar, E.; Kutsal, T.; Denizli, A. Surface imprinted bacterial cellulose nanofibers for cytochrome c purification. Process Biochem. 2015, 50, 2289-2297. [CrossRef]

205. Yang, C.; Chen, C.; Pan, Y.; Li, S.; Wang, F.; Li, J.; Li, N.; Li, X.; Zhang, Y.; Li, D. Flexible highly specific capacitance aerogel electrodes based on cellulose nanofibers, carbon nanotubes and polyaniline. Electrochim. Acta 2015, 182, 264-271. [CrossRef]

206. Wang, F.; Li, D. Foldable and free-standing 3D network electrodes based on cellulose nanofibers, carbon nanotubes and elongated $\mathrm{TiO}_{2}$ nanotubes. Mater. Lett. 2015, 158, 119-122. [CrossRef]

207. Liu, Q.; Li, J.; Zhao, Y.; Zhou, Y.; Li, C. CdS nanoparticle-functionalized natural cotton cellulose electrospun nanofibers for visible light photocatalysis. Mater. Lett. 2015, 138, 89-91. [CrossRef]

208. Snyder, A.; Bo, Z.; Moon, R.; Rochet, J.C.; Stanciu, L. Reusable photocatalytic titanium dioxide-cellulose nanofiber films. J. Colloid Interface Sci. 2013, 399, 92-98. [CrossRef]

209. He, X.; Cheng, L.; Wang, Y.; Zhao, J.; Zhang, W.; Lu, C. Aerogels from quaternary ammonium-functionalized cellulose nanofibers for rapid removal of $\mathrm{Cr}(\mathrm{VI})$ from water. Carbohydr. Polym. 2014, 111, 683-687. [CrossRef]

210. Volk, N.; He, R.; Magniez, K. Enhanced homogeneity and interfacial compatibility in melt-extruded cellulose nano-fibers reinforced polyethylene via surface adsorption of poly(ethylene glycol)-block-poly(ethylene) amphiphiles. Eur. Polym. J. 2015, 72, 270-281. [CrossRef]

211. Frone, A.N.; Nicolae, C.A.; Gabor, R.A.; Panaitescu, D.M. Thermal properties of water-resistant starch-Polyvinyl alcohol films modified with cellulose nanofibers. Polym. Degrad. Stab. 2015, 121, 385-397. [CrossRef]

212. Abdulkhani, A.; Hosseinzadeh, J.; Ashori, A.; Dadashi, S.; Takzare, Z. Preparation and characterization of modified cellulose nanofibers reinforced polylactic acid nanocomposite. Polym. Test. 2014, 35, 73-79. [CrossRef]

213. Almasi, H.; Ghanbarzadeh, B.; Dehghannya, J.; Entezami, A.A.; Asl, A.K. Novel nanocomposites based on fatty acid modified cellulose nanofibers/poly(lactic acid): Morphological and physical properties. Food Packag. Shelf Life 2015, 5, 21-31. [CrossRef]

214. Panaitescu, D.M.; Frone, A.N.; Ghiurea, M.; Chiulan, I. Influence of storage conditions on starch/PVA films containing cellulose nanofibers. Ind. Crops Prod. 2015, 70, 170-177. [CrossRef]

215. Zhou, C.; Chu, R.; Wu, R.; Wu, Q. Electrospun polyethylene oxide/cellulose nanocrystal composite nanofibrous mats with homogeneous and heterogeneous microstructures. Biomacromolecules 2011, 12, 2617-2625. [CrossRef] [PubMed]

216. Liu, P.; Oksman, K.; Mathew, A.P. Surface adsorption and self-assembly of $\mathrm{Cu}(\mathrm{II})$ ions on TEMPO-oxidized cellulose nanofibers in aqueous media. J. Colloid Interface Sci. 2016, 464, 175-182. [CrossRef] [PubMed]

217. Zhao, J.; Wang, Z.; Wang, J.; Wang, S. High-performance membranes comprising polyaniline nanoparticles incorporated into polyvinylamine matrix for $\mathrm{CO}_{2} / \mathrm{N}_{2}$ separation. J. Memb. Sci. 2012, 403-404, $203-215$. [CrossRef]

218. Zhao, S.; Wang, Z.; Qiao, Z.; Wei, X.; Zhang, C.; Wang, J.; Wang, S. Gas separation membrane with $\mathrm{CO}_{2}$-facilitated transport highway constructed from amino carrier containing nanorods and macromolecules. J. Mater. Chem. A 2013, 1, 246-249. [CrossRef]

219. Nikolaeva, D.; Luis, P. Top-down polyelectrolytes for membrane-based post-combustion $\mathrm{CO}_{2}$ capture. Molecules 2020, 25, 323. [CrossRef]

220. Li, Y.; Wang, S.; Wu, H.; Guo, R.; Liu, Y.; Jiang, Z.; Tian, Z.; Zhang, P.; Cao, X.; Wang, B. High-performance composite membrane with enriched $\mathrm{CO}_{2}$-philic groups and improved adhesion at the interface. In Proceedings of the ACS Applied Materials and Interfaces; American Chemical Society: Washington, DC, USA, 2014; Volume 6, pp. 6654-6663.

221. Robeson, L.M. Polymer blends in membrane transport processes. Ind. Eng. Chem. Res. 2010, 49, 11859-11865. [CrossRef]

222. Mitra, T.; Bhavsar, R.S.; Adams, D.J.; Budd, P.M.; Cooper, A.I. PIM-1 mixed matrix membranes for gas separations using cost-effective hypercrosslinked nanoparticle fillers. Chem. Commun. 2016, 52, 5581-5584. [CrossRef]

223. Jahan, Z.; Niazi, M.B.K.; Hägg, M.B.; Gregersen, Ø.W. Cellulose nanocrystal/PVA nanocomposite membranes for $\mathrm{CO}_{2} / \mathrm{CH}_{4}$ separation at high pressure. J. Memb. Sci. 2018, 554, 275-281. [CrossRef] 
224. Khan, M.Y.; Khan, A.; Adewole, J.K.; Naim, M.; Basha, S.I.; Aziz, M.A. Biomass derived carboxylated carbon nanosheets blended polyetherimide membranes for enhanced $\mathrm{CO}_{2} / \mathrm{CH}_{4}$ separation. J. Nat. Gas Sci. Eng. 2020, 75, 103156. [CrossRef]

225. Wu, S.Y.; Hsiao, I.C.; Liu, C.M.; Mt Yusuf, N.Y.; Wan Isahak, W.N.R.; Masdar, M.S. A novel bio-cellulose membrane and modified adsorption approach in $\mathrm{CO}_{2} / \mathrm{H}_{2}$ separation technique for PEM fuel cell applications. Int. J. Hydrogen Energy 2017, 42, 27630-27640. [CrossRef]

226. Zhang, X.F.; Feng, Y.; Wang, Z.; Jia, M.; Yao, J. Fabrication of cellulose nanofibrils/UiO-66-NH2 composite membrane for $\mathrm{CO}_{2} / \mathrm{N}_{2}$ separation. J. Memb. Sci. 2018, 568, 10-16. [CrossRef]

227. Venturi, D.; Grupkovic, D.; Sisti, L.; Baschetti, M.G. Effect of humidity and nanocellulose content on Polyvinylamine-nanocellulose hybrid membranes for $\mathrm{CO}_{2}$ capture. J. Memb. Sci. 2018, 548, 263-274. [CrossRef]

Publisher's Note: MDPI stays neutral with regard to jurisdictional claims in published maps and institutional affiliations.

(C) 2020 by the authors. Licensee MDPI, Basel, Switzerland. This article is an open access article distributed under the terms and conditions of the Creative Commons Attribution (CC BY) license (http://creativecommons.org/licenses/by/4.0/). 